Pharmacol Ther. 2017 December ; 180: 77-89. doi:10.1016/j.pharmthera.2017.06.007.

\title{
Targeting inflammation for the treatment of alcoholic liver disease
}

\author{
Ming-Jiang Xu ${ }^{\mathrm{a}, 1}$, Zhou Zhou ${ }^{\mathrm{a}, 1}$, Richard Parker ${ }^{\mathrm{a}, \mathrm{b}}$, and Bin Gao ${ }^{\mathrm{a},{ }^{*}}$ \\ aLaboratory of Liver Diseases, National Institute on Alcohol Abuse and Alcoholism, National \\ Institutes of Health, Bethesda, MD 20892, USA \\ ${ }^{b}$ Centre for Liver Research, University of Birmingham, United Kingdom
}

\begin{abstract}
Alcoholic liver disease (ALD) is a leading cause of chronic liver disease with a wide spectrum of manifestations including simple steatosis to steatohepatitis, cirrhosis, and hepatocellular carcinoma. Liver injury in ALD is caused by chronic inflammation, which has been actively investigated as a therapeutic target for the treatment of ALD for over the last four decades. In this review, we summarize a wide variety of inflammatory mediators that have been shown to contribute to the pathogenesis of ALD, and discuss the therapeutic potential of these mediators for the treatment of ALD.
\end{abstract}

\section{Introduction}

Alcoholic liver disease (ALD) is a major chronic liver disease which causes significant mortality worldwide. Chronic inflammation is a critical element in the development of ALD (Gao \& Tsukamoto, 2016; Wang, Gao, Zakhari and Nagy, 2012). Inflammation is a series of responses to harmful stimuli with which the body maintains homeostasis, but which may cause collateral damage to normal tissue (Medzhitov, 2008). In ALD, inflammation is a consequence of excessive alcohol consumption causing direct and indirect damage to the liver, eventually leading to fibrosis and impaired liver function. Over the last four decades, clinical and experimental studies of ALD have identified many inflammatory mediators that play important roles in the pathogenesis of ALD (Gao \& Tsukamoto, 2016; Wang, Gao, et al., 2012). In the present review article, we summarize the possible therapeutic targets on ALD to control inflammation that may induce liver damage, and these targets include inflammatory cytokines, immune cells, microRNAs, and gut microbiome.

\footnotetext{
Financial support: This work from Dr. Bin Gao's lab described in this review article was supported by the intramural program of NIAAA, NIH (B.G.).

${ }^{2}$ Conflict of interest: The authors declare that there are no conflicts of interest.

*Corresponding author at: NIAAA/NIH, 5625 Fishers Lane, Bethesda, 20892, USA. bgao@ mail.nih.gov (B. Gao).

${ }^{1}$ Contributed equally to this work.
} 


\section{Potential targets of immune cells for the treatment of ALD}

\subsection{Role of Kupffer cells (KCs) in alcoholic liver injury}

KCs are resident macrophages in the liver (Ju \& Tacke, 2016). They play important roles in the elimination of toxins and cell debris. KCs are activated by multiple factors in ALD, including gut-derived lipopolysaccharide (LPS), complement, and reactive oxygen species (ROS). Depleting $\mathrm{KCs}$ with $\mathrm{GdCl}_{3}$, a macrophage-specific toxin, significantly reduced the injury in an ALD model (Adachi, Bradford, Gao, Bojes, \& Thurman, 1994), suggesting that $\mathrm{KCs}$ are necessary for the development of ALD.

Alcohol ingestion compromises intestinal barrier function and increases the flux of lipopolysaccharide (LPS), derived from the bacterial cell wall, to the portal vein (Szabo \& Bala, 2010). Excess LPS activates KCs by binding to toll-like receptor 4 (TLR4) (Uesugi, Froh, Arteel, Bradford, \& Thurman, 2001), leading to nuclear factor kappa-light-chainenhancer of activated B cells (NF- $\mathrm{kB}$ ) activation and secretion of inflammatory cytokines, including tumor necrosis factor alpha (TNF-a) (Gustot et al., 2006; Yamashina et al., 2005). A MyD88 independent signal pathway passes the signal from TLR4 to TIR-domaincontaining adapter-inducing interferon- $\beta$ (TRIF), TANK Binding Kinase (TBK) 1 , inhibitor$\kappa \mathrm{B}$ kinase $\varepsilon$ (IKKe) and finally the transcription factor interferon-regulatory factor (IRF) 3 . IRF3 controls TNF- $a$ gene expression by directly binding to its promoter. TRIF deficient mice, in which the TRIF pathway is absent, are resistant to alcoholic liver injury (Zhao et al., 2008). TLR4 also regulates KCs in alcoholic liver injury through extracellular signalregulated kinase (ERKs) pathways. Among them, the TLR $4 \rightarrow$ ERK $1 / 2 \rightarrow$ early growth response protein 1 (Egr-1) $\rightarrow$ TNF-a signal is the most recognized (Kishore, Hill, McMullen, Frenkel, \& Nagy, 2002). Egr-1 deficient mice given chronic ethanol treatment have lower levels of hepatic TNF-a expression, alanine aminotransferase (ALT) elevation and hepatic steatosis than wild-type mice. The hypersensitivity of KCs to LPS stimulation is also abolished in Egr-1 deficient mice (McMullen et al., 2005). ERK1/2 signaling may also contribute to NF- $\kappa \mathrm{B}$ activation as PD98059, an ERK1/2 inhibitor reduces the activation of NF-кB (Cao, Mak, \& Lieber, 2002). Moreover, p38 phosphorylation is also upregulated after LPS stimulation, especially in ethanol-treated macrophages (Kishore, McMullen, \& Nagy, 2001). SB203580, an inhibitor of p38, reduces the expression of TNF- $a$ from KCs isolated from chronically ethanol-treated rats (Cao et al., 2002). P38 exerts this function by stabilizing TNF-a mRNA (Kishore et al., 2001). Conversely, Poly I:C, a TLR3 agonist, protectes mice from alcoholic liver injury by reducing the activation of NF- $\kappa \mathrm{B}$ and the downstream inflammatory cytokines and chemokines (Byun, Suh, Yi, Lee, \& Jeong, 2013).

Accumulating evidence shows an important contribution of KC-derived ROS in the pathogenesis of alcoholic liver injury. ROS sensitize the TLR4 pathway and independently stimulate the expression of TNF-a. Nicotinamide adenine dinucleotide phosphate (NAPDH) oxidase in KCs is believed to be the most important source of ROS (Thakur, Pritchard, McMullen, Wang, \& Nagy, 2006). Blocking its function with the NAPDH oxidase inhibitor diphenyleneiodonium (DPI) or gene knock-out alleviates inflammation and liver injury (Thakur et al., 2006). The increase in production of TNF-a by alcohol treated KCs stimulated with LPS in vitro is abrogated by DPI (Thakur et al., 2006) and daily injection of 
DPI reduces the up-regulation of TLR4 mRNA in chronically alcohol treated rats (Gustot et al., 2006). Deficiency of p47, a subunit of NADPH oxidase, protectes mice from alcoholic liver injury by reducing ROS production and TNF-a production in KCs (Kono et al., 2000). In contrast, stimulation of the activity of NADPH oxidase with arachidonic acid augmentes ROS production and TNF-a expression in KCs (Cubero \& Nieto, 2012).

The complement pathway is another important pathway of $\mathrm{KC}$ activation. $\mathrm{KCs}$ express a high amount of the complement receptors C3aR and C5aR (Qin \& Gao, 2006). Alcohol administration rapidly causes deposition of $\mathrm{C} 3 \mathrm{~b}-\mathrm{iC} 3 \mathrm{~b} / \mathrm{C} 3 \mathrm{c}$ complex in the liver. $\mathrm{C} 3$ deficient mice are resistant to alcohol induced liver steatosis (Bykov, Jauhiainen, et al., 2007) and do not show upregulation of inflammatory genes. Mice deficient of C3aR, C5aR or depletion of KCs all show diminished TNF- $a$ induction during treatment with alcohol. These findings suggest that complement deposition and signal through $\mathrm{C} 3 \mathrm{aR} / \mathrm{C} 5 \mathrm{aR}$ to $\mathrm{KCs}$ are responsible for early inflammatory gene induction after alcohol ingestion (Roychowdhury et al., 2009). The mechanisms of ethanol-induced TNF- $a$ expression in KC are summarized in Fig. 1.

2.1.1. Therapeutic targeting of KCs for treatment of ALD-Inhibition of KCs via the reduction of LPS had beneficial effects for the treatment of ALD in animal models as described above. Indeed, liver injury is reduced by preventing LPS flux from the intestine through depleting normal intestinal microflora with antibiotics or improving intestinal barrier function (Adachi, Moore, Bradford, Gao, \& Thurman, 1995; Gustot et al., 2006; Peng, Cui, et al., 2013). Current clinical studies targeting gut microbiota for the treatment of alcoholic hepatitis (AH) are described in the later paragraph in this paper. Inhibition of ROS production via the treatment with anti-oxidants (e.g. $\mathrm{N}$-acetylecysteine, vitamin E) has shown mixed results in clinical trials (Nguyen-Khac et al., 2011; Phillips et al., 2006; Stewart et al., 2007). More clinical studies are required to clarify the therapeutic benefits of anti-oxidants for the treatment of $\mathrm{AH}$.

In contrast to the devastating effect in alcoholic liver damage, KCs also promote liver regeneration, which may be a critical process of liver recovery after alcohol challenge. $\mathrm{KC}$ depletion significantly compromises liver regeneration after partial hepatectomy and partial liver transplantation (Luo, Ma, Qu, \& Tian, 2015;Meijer et al., 2000), while activation of KCs improves liver regeneration in these animal models (Yoshiya et al., 2015). KCs promote liver regeneration through the production of TNF- $a$ and IL-6, which activate NF- $k B$ and STAT3 signals respectively to reduce hepatocyte apoptosis and increase their proliferation (Abshagen, Eipel, Kalff, Menger, \& Vollmar, 2007; Luo et al., 2015; Yang et al., 2013; Yoshiya et al., 2015). Given these important functions of KCs in liver regeneration, long term inhibition of KCs may not be a good choice as a therapeutic target of ALD. Instead, keeping functional $\mathrm{KCs}$ in the recovery phase after eliminating the source of damage may be beneficial.

\subsection{Role of neutrophils in ALD}

Neutrophils are central to the development of ALD. Unlike other innate immune cells, neutrophils are not residential immune cells in the liver. The infiltration of neutrophils to the liver is a critical and necessary step for their biological functions. Neutrophils exert their 
damaging effects in ALD via the release of tissue dissolving enzymes and the production of ROS (Jaeschke, 2002). Depletion of neutrophils reduces liver damage in chronic-plus-binge mouse model (Bertola, Park, \& Gao, 2013).

Neutrophils are typically attracted by CXC chemokines, such as CXCL8 (IL-8) in humans, CXCL1 in mice and cytokine-induced neutrophil chemoattractant in rats (Bautista, 2002). These cytokines are upregulated in clinical and experimental ALD (Chang et al., 2015; Roh, Zhang, Loomba, \& Seki, 2015) (Shiratori et al., 1994). AH patients have elevated expression of many CXC and CC chemokines than healthy individuals, including IL-8, Gro-a, CXCL5, CXCL6, CXCL10, CCL20 and platelet factor 4. The expression of these chemokines correlates with the neutrophil infiltration and the severity of portal hypertension (Affo et al., 2013; Dominguez et al., 2009). A recent study also demonstrated that AH patients had a significant increase in albumin oxidation, which acts as a pro-oxidant that induces ROS and inflammation via the activation of neutrophils, suggesting a pathogenic role of neutrophils in AH (Das et al., 2017).

Intercellular Adhesion Molecule 1 (ICAM-1) is expressed constitutively on endothelial cells and reacts to the integrin CD11/CD18 on neutrophils to cause adhesion. During chronic alcohol intoxication, ICAM-1 expression is upregulated in hepatocytes, which facilitates the direct contact of neutrophils and hepatocytes (Bautista, 1997; Jaeschke, 2002). ICAM-1 deficient mice showed apparent resistance to alcohol induced liver injury (Kono et al., 2001). Another important molecule that mediates infiltration of neutrophils to liver is osteopontin (OPN), a matricellular protein that binds to integrins on neutrophils. In a model of alcoholic steatohepatitis induced by feeding Lieber-DeCarli diet plus LPS injection in rats, OPN expression is highly elevated. The elevation of OPN expression correlates with neutrophil infiltration and liver injury (Apte, Banerjee, McRee, Wellberg, \& Ramaiah, 2005; Banerjee, Apte, Smith, \& Ramaiah, 2006). However, a recent study using OPN deficient mice showe conflicting results regarding the role of OPN in a hybrid model with severe ALD. OPN deficient mice showe a tendency towards increased neutrophil infiltration and liver damage, although statistical significance was not reached (Lazaro et al., 2015). Thus, OPN may have a complicated function in alcoholic steatohepatitis. Finally, our recent study revealed that hepatic E-selectin is highly expressed in the chronic-plus-binge mouse model and human alcoholic fatty livers. Knockout of E-selectin diminished hepatic neutrophil infiltration and liver injury in the chronic-plus-binge ethanol feeding model (Bertola et al., 2013).

Neutrophils may also migrate in response to lipid signaling: Perez et al. provided evidence that hepatocytes generated a lipid material which was chemo-attractive to neutrophils (Perez, Roll, Bissell, Shak, \& Goldstein, 1984), although the exact chemical nature of this lipid is not fully defined (Roll, Alexander, \& Perez, 1989; Roll, Bissell, \& Perez, 1986). Free fatty acids may be another source of signal for the production of CXCL1 (Chang et al., 2015; Roh et al., 2015). Hepatic CXCL1 is highly upregulated after high-fat diet (HFD)-plus-binge alcohol feeding, and blockage of CXCL1 markedly reduces HFD-plus-binge ethanolinduced hepatic neutrophil infiltration and liver injury (Chang et al., 2015). 
In contrast to the evidence that neutrophils induce hepatocellular damage in animal models, histological studies in patients with severe AH have shown that greater neutrophil infiltration is associated with better outcome suggesting that presence of neutrophils is of benefit (Altamirano et al., 2014). The beneficial effect of neutrophils in severe AH may be because neutrophils play important roles in inhibiting bacterial infection and stimulating liver regeneration (Kwon, Won, Park, Feng, \& Gao, 2014).

2.2.1. Therapeutic targeting of neutrophils for treatment of ALD—As neutrophils can play both detrimental (e.g. damaging hepatocytes) and beneficial (e.g. inhibiting bacterial infection and stimulating liver regeneration) roles in the pathogenesis of ALD, it may be more beneficial to restore neutrophil function in patients with ALD, rather than to seek to deplete or inhibit neutrophils in these patients. Indeed, there are some data suggesting that mobilization of neutrophils from the bone marrow with granulocyte colony stimulating factor (G-CSF) may be of benefit in AH (Singh et al., 2014).

\section{3. $T$ cells in ALD}

It was reported that patients with $\mathrm{AH}$ had elevated circulating antibodies against lipid peroxidation adducts and significant infiltration of T cells in the liver (Albano \& Vidali, 2010; Thiele, Freeman, \& Klassen, 2004; Thiele et al., 2010). Other studies demonstrated hepatic T cells in ALD produced IL-17, and levels of IL-17 correlated with liver inflammation and injury (Lemmers et al., 2009). It is generally believed that excessive alcohol consumption causes hepatic oxidative stress, which then induces lipid peroxidation products (e.g. malondialdehyde and 4-hydroxynonenal) (Albano \& Vidali, 2010; Thiele et al., 2004, 2010). These products then interact with many proteins to form protein adducts that can act as antigens to activate the adaptive immune response (Albano \& Vidali, 2010; Liaskou et al., 2016; Thiele et al., 2004, 2010). However, the exact roles of adaptive immunity and T cells in the pathogenesis of ALD remain to be elusive. Future studies are urgently needed to unravel their functions to explore whether T cells and adaptive immunity are potential therapeutic targets for the treatment of ALD.

\subsection{Natural killer (NK) and NKT cells in ALD}

NK cells exert an anti-fibrotic effect in liver diseases (Jeong et al., 2011; Krizhanovsky et al., 2008; Peng, Jiang, et al., 2013; Radaeva et al., 2006). This effect primarily relies on NK cell killing of activated hepatic stellate cells (HSCs) (Jeong et al., 2011; Radaeva et al., 2006). Although NK cells effectively reduce liver fibrosis, alcohol drinking compromises this protective function through several mechanisms. First, chronic alcohol consumption hinders the development of conventional NK cells. Alcohol consumption directly prohibits the development of NK cells in the CD11 b ${ }^{+} \mathrm{CD} 27^{+}$stage (Zhang, Little, \& Zhang, 2017). Lack of IL-15/IL-15R signal availability is likely the reason of this effect of alcohol consumption, because restoring this signal recovers the NK cell number and activity (Zhang et al., 2017). Second, chronic alcohol feeding reduces conventional NK cell number in the liver and compromises the cytolytic functions of NK cells (Pan et al., 2006). NK cells from ethanol-fed mice have reduced expression of NKG2D, TRAIL and IFN- $\gamma$ (Ben-Eliyahu, Page, Yirmiya, \& Taylor, 1996; Jeong, Park, \& Gao, 2008; Laso et al., 1997; Meadows, Blank, \& Duncan, 1989). The shortage of these key molecules may explain the low cytolytic 
activity of NK cells in ethanol-fed animals. Third, alcohol drinking increases the expression of suppressor of cytokine signaling (SOCS) 1 and TGF- $\beta$ in HSCs (Jeong et al., 2008). SOCS1 is a natural antagonizing protein of the IFN- $\gamma$-STAT1 pathway. Increased SOCS1 expression diminishes the cell cycle arrest and apoptosis effect of IFN- $\gamma$ on HSCs. TGF- $\beta$ is a potent factor to inhibit the immune cell functions, including NK cell. By inducing the expression of TGF- $\beta$ and SOCS1 in HSCs, alcohol consumption enhances the resistance of HSCs to the cytolytic activity of NK cells (Jeong et al., 2008). Thus, alcohol consumption enhances liver fibrosis by diminishing the endogenous anti-fibrotic mechanism provided by NK cells. This may underlie the effect of alcohol consumption in accelerating liver fibrosis from other fibrotic challenges.

NKT cells are another type of innate immune cells, which are enriched in the liver and play important roles in the pathogenesis of liver diseases (Bandyopadhyay, Marrero, \& Kumar, 2016; Gao, Radaeva, \& Park, 2009; Wang, Feng, Park, Yin, \& Gao, 2013; Yin et al., 2014). NKT cells recognize lipid antigens presented by CD1d molecules. Interestingly, type I NKT cells and type II NKT cells are discovered to play opposite roles in the control of liver injury. Type I NKT cells are typically highly activated by $a-G a l C e r$ and express IL-4 and IFN- $\gamma$. Theymanipulate other immune cells including neutrophils to induce liver injury (Maricic et al., 2015). In the chronic-plus-binge ethanol model, type I NKT cells are recruited and activated by IL-1 $\beta$ produced by KCs (Cui et al., 2015; Mathews et al., 2016). Alcohol may also facilitate the assembly of $\alpha$-GalCer to CD1d so that the type I NKT cells are easily activated in alcohol drinking (Buschard et al., 2011). In contrast, type II NKT cells are activated by sulfatide and inhibit the activity of type I NKT cells. Activation of type II NKT cells ameliorates liver damage in the chronic-plus-binge ethanol model (Maricic et al., 2015). As type I NKT cells are activated but type II NKT cells are not activated in alcohol drinking, manipulating the activation of these two cell subtypes may have therapeutic potential for the treatment of ALD (Maricic et al., 2015).

\subsubsection{Therapeutic targeting of NK and NKT cells for treatment of ALD-NK}

cells have many beneficial effects in the liver, such as host defense against viral infection and tumor transformation, and anti-fibrotic functions. It is known that NK cell functions are suppressed in patients with ALD; thus restoration of NK cell functions may have therapeutic potential for the treatment of ALD (Gao et al., 2009).

NKT cells seemto play complex roles in the pathogenesis of ALD, and different types of NKT cells play opposite roles in the control of liver injury. More studies are needed to demonstrate whether NKT cells can be used as therapeutic targets for the treatment of ALD.

\subsection{Potential role of innate lymphoid cells (ILCs) in ALD}

ILCs are groups of lymphoid cells that belong to the innate immune system, and are usually divided into 3 groups according to the cytokine expression pattern in counterpart of helper $\mathrm{T}$ (Th) cells. Group 1 ILCs, which resemble the Th1 cells, express transcription factor T-bet and express Th1 cytokines IFN- $\gamma$ and TNF- $\alpha$ to defend intracellular pathogens upon the activation of IL-12, IL-15 and IL-18 (Eberl, Colonna, Di Santo, \& McKenzie, 2015; Sonnenberg \& Artis, 2015). Group 2 ILCs are the counterpart of Th2 cells as they both 
express transcription factor GATA3 and have similar function. They are built to protect from the extracellular parasites by receiving the signal from IL-25, IL-33, TSLP (thymic stroma lymphopoietin) and IL-4 to produce IL-4, IL-5, IL-9, IL-13 and amphiregulin. The counterpart of Th17 cells in the ILCs are the group 3 ILCs and they express transcription factor ROR $\gamma$ t. Upon the activation with IL-33 and IL-1 $\beta$, they produce IL-17, IL-22, GMCSF and lymphotoxins. The Group 3 ILCs are dedicated to defending the invading fungi and extracellular bacteria (Eberl et al., 2015; Sonnenberg \& Artis, 2015). Modern classification of ILCs also casts NK cells alone as killer ILCs because of the direct cytotoxicity through expressing granzymes and perforin. The rest ILCs are called helper-like ILCs and further divided into groups mentioned above (Diefenbach, Colonna, \& Koyasu, 2014; Eberl et al., 2015).

ILCs are important immune cells in the initiation and resolution of both acute and chronic inflammation in gastrointestinal and airway mucosa as well as in the pathogenesis of liver diseases (Eberl et al., 2015; Sonnenberg \& Artis, 2015; Yang, Tian, Wu, van Velkinburgh, \& $\mathrm{Ni}, 2015)$. To date, the roles of ILCs in the pathogenesis of ALD remain poorly understood. Given the substantial pathogenic effects of cytokines produced by ILCs in ALD, ILCs likely play an important role in the control of liver inflammation and injury in ALD. Future studies are required to identify the role of ILCs in the pathogenesis of ALD.

\section{Pro-inflammatory cytokines and chemokines}

Over the last four decades, studies using rodent models of ALD and human ALD samples have identified multiple inflammatory mediators that play important roles in the pathogenesis of ALD (Gao \& Tsukamoto, 2016; Wang, Gao, et al., 2012). Although immune cells are the great sources of pro-inflammatory cytokines and chemokines, such as IL-8, TNF-a, CXCL1, IL-1, IL-17, CCL20, MCP-1 et al., hepatocytes and non-parenchymal liver cells also produce mediators including IL-1, TNF-a, CXCL1/GROa, OPN, MCP-1, LCN-2 etc. The role of these pro-inflammatory cytokines and chemokines in the pathogenesis of ALD are summarized in Table 1.

\subsection{TNF-a}

AH patients demonstrate a high level of TNF- $a$, and TNF- $a$ is also induced in alcohol-fed animals and is closely coupled with liver injury (Wang, Gao, et al., 2012). However, both chimeric monoclonal antibody to TNF-a (infliximab) and p75-soluble TNF receptor:FC fusion protein (etanercept) showed no benefit in clinical trials, instead both treatments increased mortality due to an increased incidence of severe infections (Boetticher et al., 2008; Naveau et al., 2004), leading to the early cessation of the studies. Pentoxifylline, an orally administered phosphodiesterase inhibitor was thought to have a beneficial effect on AH via the reduction of TNF-a but this has been shown to be ineffective for the treatment of severe AH (Thursz et al., 2015).

\subsection{IL-8, CXCL1/GROa}

As discussed above, neutrophil infiltration is a key feature of AH (Gao \& Tsukamoto, 2016). IL-8 and CXCL1/GROa are the two most important chemokines for neutrophil recruitment. 
Serum and hepatic levels of IL-8 and CXCL1/GROa are elevated in AH patients, and correlate with hepatic neutrophils infiltration, disease severity and mortality (Dominguez et al., 2009; Maltby et al., 1996; Patel et al., 2015; Sheron et al., 1993). Patients with alcoholic cirrhosis have increased frequency of the rs4074 A allele and enhanced CXCL1 serum levels, indicating the CXCL1 rs4074 A allele as a genetic risk factor for alcoholic cirrhosis (Nischalke et al., 2013). In alcohol-fed animal models, blockade of IL-8 receptors (CXCR1/2) protects mice from liver injury, inflammation, steatosis, weight loss and mortality (Roh et al., 2015; Wieser, Adolph, et al., 2017). We recently also showed that CXCL1 was dramatically upregulated in HFD-plus-binge ethanol-exposed mice and CXcl1 knockout or anti-CXCL1 treatment protected mice against HFD-plus-binge ethanol-induced neutrophil-mediated liver injury (Chang et al., 2015). Thus, blockade of IL-8/CXCL1induced neutrophil infiltration could be a potential therapeutic strategy for AH treatment. Interestingly, a recent study revealed that activation of peroxisome proliferator-activated receptor gamma markedly attenuated CXCL1 expression in hepatocytes and reduces hepatic neutrophil infiltration in high-fat diet-plus-binge ethanol fed mice (Wang et al., 2017), suggesting that manipulation of peroxisome proliferator-activated receptor gamma may also be a potential strategy to treat ALD via the inhibition of CXCL1 expression.

\subsection{IL-1}

The expression of IL-1 $\beta$, an important pro-inflammatory cytokine, is upregulated in AH patients and correlates with disease severity and short term mortality (McClain et al., 1986; Tilg, Moschen, \& Szabo, 2016). The haplotype, IL-1b 2511 allele 2/13953 allele 1, is associated with the development of alcoholic cirrhosis (Takamatsu et al., 2000). IL1b $-511 \mathrm{CC}$ genotype influences the total bilirubin, albumin and ALT levels among alcoholic "Bengalis" (Roy et al., 2012). IL-1 $\beta$ is secreted by KCs via the activation of inflammasome and Caspase-1 (Mathews \& Gao, 2013). An important role of the inflammasome-Caspase-1IL-1 $\beta$ signaling in the pathogenesis of AH was reported in mice, and antagonizing IL-1 $\beta$ with IL-1Ra diminished the liver injury, suggesting a potential therapeutic strategy to treat ALD by blocking the inflammasome-Caspase-1-IL-1 $\beta$ signaling (Petrasek et al., 2012; Tilg et al., 2016). The IL-1 receptor antagonist Anakinra and the IL-1 inhibitor Rilonacept are currently being evaluated in a clinical trial for severe AH (NCT01809132;

NCT01903798).

\subsection{IL-17}

IL-17, a potent pro-inflammatory cytokine, participates in ALD by promoting both liver inflammation and fibrosis (Wang, Gao, et al., 2012). Several recent studies have shown that serum IL-17 levels and hepatic IL-17 ${ }^{+}$cell infiltration are increased in patients with AH and in mice with ALD (Chen et al., 2016; Shi et al., 2013; Stoy et al., 2013). HSCs produce IL-8 and GROa upon IL-17 stimulation. Hepatic infiltration of IL-17 producing cells also correlates with liver fibrosis (Lemmers et al., 2009). Moreover, anti-IL-17 antibody treatment ameliorates liver steatosis in animal models (Shi et al., 2013). Thus, IL-17 is a potential target for the treatment of ALD. 


\subsection{CCL20}

CCL20 is a chemokine highly expressed in peripheral blood lymphocytes, lymph nodes, the liver, the appendix, and the fetal lung upon the stimulation of many inflammatory mediators like LPS, TNF- $a$, and IL-1 $\beta$ (Gao \& Xu, 2014). The major target cells of CCL20 are lymphocytes. However, they can also attract neutrophils to a less extent through the binding of CCR6, which is found to regulate liver inflammation, fibrosis, and tumorigenesis (Aoki et al., 2011; Hammerich et al., 2014; Oo et al., 2012). Patients with AH have high serum levels of CCL20, which correlate with endotoxemia, liver fibrosis, portal hypertension, disease severity score, and short-term mortality (Affo et al., 2014). Macrophages and HSCs are major producers of CCL20 in mouse models of $\mathrm{CCl}_{4}$ plus ethanol and $\mathrm{CCl}_{4}$ plus LPS (Affo et al., 2014). Silencing CCL20 reduces LPS-induced liver inflammation and injury (Affo et al., 2014).

\subsection{Osteopontin (OPN)}

OPN is an extracellular matrix protein that has been implicated in the pathogenesis of liver injury, inflammation, and fibrogenesis. Serum and hepatic OPN levels are increased in patients with $\mathrm{AH}$ and correlate with disease severity and short term mortality (Affo et al., 2013; Morales-Ibanez et al., 2013; Patouraux et al., 2012; Seth et al., 2014). OPN gene knockout reduced chronic-plus-binge ethanol-induced liver steatosis, inflammation and injury (Morales-Ibanez et al., 2013). However, recent studies in OPN deficient mice revealed a slight but statistically non-significant improvement in liver injury in a chronic ethanol feeding model and a hybrid model with intragastric ethanol feeding plus multiple binges (Ge et al., 2014; Lazaro et al., 2015). It is possible that OPN only participates in the early stage of ALD, but not in the severe or late stages. Thus, OPN may not be a good therapeutic target for the treatment of ALD.

\subsection{Lipocalin 2 (LCN2)}

LCN2 was originally isolated from neutrophils and termed neutrophil gelatinase-associated lipocalin (NGAL). Recent studies show increased hepatic LCN2 levels in patients with ALD (Affo et al., 2013; Wieser, Tymoszuk, et al., 2016). Similar increases of serum and hepatic LCN2 levels were also observed in ethanol-fed mice, and LCN2 deficiency ameliorated liver steatosis, inflammation and liver injury after chronic ethanol feeding (Bykov, Junnikkala, Pekna, Lindros, \& Meri, 2007; Cai et al., 2016; Ki et al., 2010;Wieser, Tymoszuk, et al., 2016). In addition, chronic infusion of recombinant LCN2 exacerbated diet-induced liver injury, inflammation and macrophage accumulation in a neutrophil-dependent manner in mice with non-alcoholic steatohepatitis (Ye et al., 2016). Because LCN2 plays an important role in inhibiting bacterial infection and promoting liver regeneration (Xu et al., 2015), inhibition of LCN2 is probably not a good strategy to treat ALD although LCN2 may promote inflammation in ALD.

\section{Anti-inflammatory and hepatoprotective cytokines}

To date, only a few anti-inflammatory and hepatoprotective cytokines are identified in ALD, i.e. IL-6, IL-22, and IL-10. All of these cytokines use signal transducer and activator of transcription 3 (STAT3) signal to regulate the expression of target genes, which are involved 
in promoting cell proliferation, survival, and differentiation (Wang, Lafdil, Kong, \& Gao, 2011). IL-6 treatment ameliorated ALD in mice and improved fatty liver transplantation in rats (Chen et al., 1997; Hong et al., 2004; Sun et al., 2003). However, it is not suitable for clinical use of IL-6 therapy because of many side effects. The IL-6 receptor (IL-6R) and the gp130 signal chain are widely expressed in many types of cells, which limits the specificity in clinical use (Wang, Gao, et al., 2012).

IL-10 is a strong anti-inflammatory cytokine and can block the production of TNF- $a$, IL-1 $\beta$, and IL-6 in macrophages. Byun et al. showed that treatment with poly I:C protected against alcoholic liver injury via the stimulation of IL-10 production in HSCs and KCs (Byun et al., 2013). However, IL-10 deficiency will elevate the expression of IL-6 and STAT3 signal as compensation. This effect reduces steatosis and liver injury after chronic ethanol feeding despite the increased liver inflammation in IL-10 knockout mice (Miller et al., 2011).

In contrast to the ubiquitous expression of IL-6R and IL-10R, IL-22R expression is restricted to epithelial cells, including hepatocytes and liver progenitor cells, but is not expressed by immune cells (Kong, Feng, Mathews, \& Gao, 2013). The biological effect of IL-22 is therefore restricted to epithelial cells. This specificity should in theory minimize side effects of IL-22 in clinical usage. IL-22 treatment has been shown to ameliorate hepatocellular damage, promote liver regeneration, and alleviate liver fibrosis in several mouse models of liver injury (Kong et al., 2013). In addition, IL-22 treatment in mouse models also attenuated bacterial infection (Rubino, Geddes, \& Girardin, 2012; Zheng et al., 2016) and kidney injury (Xu, Feng, et al., 2014), two deleterious and fatal conditions related to severe AH. These beneficial functions of IL-22 make it ideal for the clinical treatment of AH (Gao \& Shah, 2015). The only concern for IL-22 therapy is its role in liver cancer. However, IL-22 transgenic mice with super high levels of serum IL-22 (>6000 pg/ml) do not spontaneously develop liver cancer, suggesting that IL-22 does not initiate the oncogenesis of liver cancer and may only impact on the existing liver cancer cell growth (Park et al., 2011). Short-term IL-22 therapy should be safe in AH patients without liver cancer. A phase $\mathrm{Ib}$ clinical trial examining IL-22 therapy for the treatment of patients with severe AH is currently ongoing in the United States (NCT02655510).

\section{The role of microRNA in inflammation of ALD}

MicroRNAs (miRNA) are a class of small non-coding RNAs involved in post-transcriptional regulation of gene expression, termed RNA interference (RNAi). In animals, pre-miRNAs are generated from the full-length primary transcript miRNAs, termed pri-miRNA through enzymatic cleavage by RNase III Drosha, and subsequently transport to the cytosol and are further processed by dicer to produce double-stranded mature miRNAs ( 22 nucleotides).

One strand is loaded into the silencing complex and imperfectly binds within the $3^{\prime}$-UTR of target transcripts to disrupt translation (Carthew \& Sontheimer, 2009). In addition to intracellular localization, miRNAs are also detected in body fluids, such as urine, bile, saliva, serum and plasma, et al. (Mitchell et al., 2008; Shigehara et al., 2011; Weber et al., 2010). Recent studies have suggested that circulating miRNAs are present in either the protein fraction or extracellular vesicles (Bala et al., 2012; Eguchi et al., 2017; MomenHeravi, Saha, et al., 2015). The high stability of circulating miRNAs makes them attractive 
for biomarker discovery in liver diseases (Szabo \& Bala, 2013). For example, miR-122 has been assessed as a biomarker for liver injury (Zhang, Jia, et al., 2010). Here we summarize the current data about miRNAs in ALD (Table 2).

Differential expression patterns of miRNAs in the liver of ALD patients and animal models have been studied (Dippold, Vadigepalli, Gonye, Patra, \& Hoek, 2013; Liu, Chen, Jin, \& Li, 2013). More recently, Blaya $D$ et al. also identified 177 differentially expressed miRNAs in the liver of ALD patients (Blaya et al., 2016). In their studies, RNA samples from liver tissue of patients with severe $\mathrm{AH}$, alcoholic cirrhosis, cirrhosis from hepatitis $\mathrm{C}$, and healthy patients were examined and compared. The most interesting finding from these studies was that among the 177 differentially expressed miRNAs in the liver of AH patients, 19 miRNAs were found specifically dysregulated in $\mathrm{AH}$ with respect to other liver diseases, including miR-182, miR-503, miR-127-3p, miR-132, miR-3201, miR-3178, miR-432, miR-3128, miR-99b, miR-409-3p, miR-134, miR-4649-5p, miR-3613-3p, miR-3175, miR-4668-5p, miR-487b, miR-423-5p, miR-500a, and miR-371b-5p. A subsequent ingenuity pathway analysis revealed that the 19 miRNAs link to pathways related to the nuclear receptors pregnane $\mathrm{X}$ receptor (PXR), retinoid X receptor (RXR) and farnesoid X receptor (FXR), and to cholestasis. These findings may provide cues for exploring novel therapeutic options for AH. For example, the link to FXR raises the hypothesis that FXR agonists, like obeticholic acid that is currently under investigation for non-alcoholic fatty liver disease and primary biliary cholangitis (PBC), may deserve testing as a new therapeutic option for AH (Stickel \& Dubuquoy, 2016).

Over the last 10 years, a large number of studies have examined the roles of miRNAs in the pathogenesis of liver diseases with a focus on hepatocyte-specific miR-122 (Wang, Heegaard, \& Orum, 2012). MiR-122 is highly abundant in hepatocytes, and plays an important role in the control of lipid metabolism, differentiation, regeneration, and tumorigenesis in the liver (Hsu et al., 2016; Simerzin et al., 2016; Wang, Heegaard, et al., 2012). Here we mainly focus on the discussion of miRNAs in liver inflammation in ALD.

\subsection{MiRNAs targeting hepatocytes and biliary epithelial cells}

A recent study reported that miR-182 was the most highly expressed miRNA in AH and the levels of miR-182 correlated with degree of ductular reaction, disease severity and shortterm mortality. MiR-182 mimic induced an upregulation of inflammatory mediators in biliary cells, suggest that miR-182 promotes liver inflammation by targeting biliary epithelial cells (Blaya et al., 2016).

\subsection{MiRNAs targeting $\mathrm{KCs} /$ macrophages}

Accumulating evidence suggests that many miRNAs also play an important role in the control of liver inflammation in ALD by targeting KCs/macrophages, which are discussed below and summarized in Table 2 .

Inflammation-associated microRNAs (inflam miRs) are a group of microRNAs that has been implicated in inflammatory responses. These include miR-223, miRNA-155, miRNA-146a, miRNA-146b, miRNA-125, and miRNA-132, miR-150, miR-181, let-7 and miR-21 (Bala \& Szabo, 2012; O’Neill, Sheedy, \& McCoy, 2011). Among them, miR-27 was found to be able 
to polarize macrophages into M2 phenotypes by targeting SPRY2 and subsequent phosphorylation of ERK (Saha et al., 2015, 2016). Chronic alcohol consumption also increases miR-155 in macrophages/KCs via an NF- $\mathrm{kB}$-dependent pathway and the increased miR-155 contributes to alcohol-induced elevation in TNF- $\alpha$ and IL- $1 \beta$ production, indicating a central functional role of miR-155 for controlling pro-inflammatory (M1) polarization in macrophages (Bala et al., 2011, 2016). Similarly, miRNA-217 is found to be increased in ethanol-treated macrophages/KCs and leads to inflammatory activity by disrupting Siruin1-lipin-1 signaling (Yin et al., 2015). More recently, Dr. Nagy's group demonstrated that miR181b-3p in KCs plays an important role in the control of liver injury and inflammation in ethanol-fed mice via the regulation of importin a 5 and sensitivity of TLR4-mediated signaling (Saikia et al., 2017). A small specific-sized hyaluronic acid 35 (HA35) treatment can normalize the dysregulated miR181b-3p in KCs and ameliorate ALD in mice, suggesting that HA35, miR-181b-3p, or combination may have therapeutic potential for the treatment of ALD (He \& Gao, 2017; Saikia et al., 2017).

\subsection{MiRNAs targeting neutrophils}

MiR-223 is a neutrophil-specific miRNA and is highly expressed in neutrophils, playing an important role in limiting neutrophil over-activation in a variety type of diseases, including drug-induced liver injury (He et al., 2017) and ALD(Li et al., 2017). In ALD, miRNA-223 is upregulated in neutrophils and serum. Mechanistically, miR-223 acts as an inhibitory factor of neutrophil activation in ALD by disrupting neutrophil IL-6 expression and subsequent $\mathrm{p} 47^{\mathrm{phox}}$-mediated ROS production, suggesting miR-223 is an important regulator to block neutrophil infiltration in ALD and is a novel therapeutic target for the treatment of ALD ( $\mathrm{Li}$ et al., 2017; Wang \& Ding, 2017).

\subsection{MiRNAs targeting intestinal epithelial cells}

Gut-derived endotoxin is considered the key cause of endotoxemia in alcohol-fed animal models and human alcoholics. Therefore, targeting intestinal epithelial cells to protect against alcohol-induced gut leakiness is essential for the development of novel therapeutic interventions for prevention and/or treatment of ALD. The integrity of the intestinal barrier depends on both healthy epithelial cells and on an intact paracellular pathway. This pathway is a complex array of structures that include tight junctions between gut epithelial cells. Cytoplasmic plaque proteins such as Zonula occludens-1 (ZO-1) constitute a major component of tight junctions (Sawada et al., 2003). There are two miRNAs that have been identified involving in alcohol-induced gut leak, i.e. miR-155 and miR-212. Similar to the effect observed in the liver, chronic ethanol-induced upregulation of miR-155 stabilizes and increases the Tnfa mRNA and decreases its molecular target Reg3b, which cause intestinal inflammation and barrier dysfunction leading to endotoxemia (Lippai et al., 2014). Increased levels of miR-212 in the intestine were reported with alcohol feeding and this increased miR-212 targets tight junction proteins like ZO-1 causing gut leakiness by down-regulating ZO-1 translation (Tang et al., 2008, 2015; Zhao et al., 2015). Probiotic supplementation of Lactobacillus rhamnosus $\mathrm{GG}$ is shown to protect intestinal barrier dysfunction by decreasing the expression of miR-122 in chronic ethanol-fed mice (Zhao et al., 2015). 


\section{Targeting intestinal microbiome for the treatment of ALD}

The gut-liver interaction plays a critical role in the pathogenesis of ALD. The mucosal microbiota, integrity of the intestinal barrier and a healthy liver ensure the optimal working of the gut-liver axis. However, alcohol exposure damages both gut mucosa and liver health. Chronic alcohol consumption results in overgrowth of intestinal gram-negative bacteria, which consequently increases endotoxin production and release (Bode, Bode, Heidelbach, Durr, \& Martini, 1984; Hauge, Persson, \& Danielsson, 1997). In addition, alcoholic patients also have gut microbiota dysbiosis and elevated gut-derived serum endotoxins (Bode, Kolepke, Schafer, \& Bode, 1993). Many factors have been found to contribute to alcohol consumption-induced intestinal dysbiosis including dietary habits, medications or xenobiotics, genetics, intestinal dysmotility, increased gastric $\mathrm{pH}$, altered bile flow, and altered immune response (Hartmann, Seebauer, \& Schnabl, 2015). Recently, Llopis M et al. showed a specific dysbiosis associated with ALD severity in patients (Llopis et al., 2016). Mice harboring the intestinal microbiota from a patient with severe AH developed greater degree of liver inflammation and necrosis, and greater intestinal permeability and higher translocation of bacteria than those harboring the intestinal microbiota from an alcoholic patient without AH (Llopis et al., 2016). More recently, a study suggests that excessive alcohol consumption is associated with an altered mycobiota and translocation of fungal products in patients and mice (Yang et al., 2017). Therefore, targeting intestinal dysbiosis and pathological bacterial and fungal translocation may help to prevent the progression of ALD. Treatment with probiotic VSL\#3 improved gut permeability in chronically alcohol fed-rats (Chang et al., 2013). Administration of Lactobacillus rhamnosus GG or CCFM1107 to alcohol-fed mice resulted in a decrease in serum endotoxin level, and alcohol-induced liver damage by improving gut permeability, reducing oxidative stress, and restoring the intestinal flora (Bull-Otterson et al., 2013; Tian et al., 2015). Supplementation of diet with saturated fatty acid reverses alcohol-induced dysbiosis and liver damage (Chen et al., 2015). Fecal microbiota transplantation demonstrated beneficial effects in prevention of alcoholinduced dysbiosis, liver inflammation and injury in mice (Ferrere et al., 2017). Fecal microbiota transplantation has been tested as a therapeutic approach in patients with persistent positive $\mathrm{HBeAg}$ and demonstrated benefits in inducing $\mathrm{HBeAg}$ clearance after long-term antiviral therapy (Ren et al., 2017). Therefore, fecal microbiota transplantation may have beneficial effects for the treatment of ALD and intestinal microbiota could be considered as a new therapeutic target in ALD.

\section{Ongoing clinical trials for the treatment of $\mathrm{AH}$}

Multiple clinical trials of anti-inflammatory treatments for $\mathrm{AH}$ are currently in progress (Table 3). All aspects of the inflammatory process are under investigation, including manipulation of the gut microbiome, promoting the development and release of neutrophils from bone marrow and agents targeted at pro-inflammatory mediators such as TNF- $a$ or LPS. It has been notoriously difficult to show a survival benefit in ALD, the recent STOPAH trial in AH being a case in point (Thursz et al., 2015). In view of this, many trials currently underway use alternatives to mortality as a primary outcome measure as shown in Table 3. 


\section{Perspective}

It is now clear that a large number of inflammatory mediators are elevated in severe forms of ALD, and these mediators likely interact with each other to synergistically promote the progression of ALD. Targeting a single inflammatory mediator will probably not be enough to control the severe inflammation in ALD. In addition, inflammation also plays an important role in promoting liver regeneration and attenuating bacterial infection. Inhibition of inflammation may further worse the ongoing poor liver regeneration and bacterial infection in severe forms of ALD. Thus, combination therapy (ie. Immunosuppression, hepatoprotection, and anti-bacterial infection) is needed for the treatment of severe ALD (Gao \& Shah, 2015).

\section{Abbreviations}

AH alcoholic hepatitis

ALD alcoholic liver disease

ALT alanine aminotransferase

CCL chemokine (C-C motif) ligand

CXCL chemokine (C-X-Cmotif) ligand

DAMP danger-associated molecular pattern

DPI diphenyleneiodonium

Egr-1 early growth response protein 1

ERK extracellular signal-regulated kinase

GROa growth-regulated alpha protein

HFD high-fat diet

HSCs hepatic stellate cells

ICAM-1 Intercellular Adhesion Molecule 1

IFN interferon

IL interleukin

IKK $\varepsilon \quad$ inhibitor- $\kappa \mathrm{B}$ kinase $\varepsilon$

IRF interferon-regulatory factor

KCs Kupffer cells

LCN2 lipocalin 2

LPS lipopolysaccharide 


$\begin{array}{ll}\text { MAPK } & \text { mitogen-activated protein kinases } \\ \text { MCP1 } & \text { monocyte chemoattractant protein-1 } \\ \text { miRNA } & \text { microRNAs } \\ \text { NAPDH } & \text { nicotinamide adenine dinucleotide phosphate } \\ \text { NF-xB } & \text { nuclear factor kappa-light-chain-enhancer of activated B cells } \\ \text { NK } & \text { natural killer } \\ \text { OPN } & \text { osteopontin } \\ \text { ROS } & \text { reactive oxygen species } \\ \text { SOCS } & \text { suppressor of cytokine signaling } \\ \text { TBK } & \text { TANK Binding Kinase } \\ \text { TGF } & \text { transforming growth factor } \\ \text { TNF } & \text { tumor necrosis factor } \\ \text { TLR } & \text { toll-like receptor } \\ \text { TRIF } & \text { TIR-domain-containing adapter-inducing interferon- } \beta\end{array}$

\section{References}

Abshagen K, Eipel C, Kalff JC, Menger MD, Vollmar B. Loss of NF-kappaB activation in Kupffer cell-depleted mice impairs liver regeneration after partial hepatectomy. American Journal of Physiology Gastrointestinal and Liver Physiology. 2007; 292:G1570-G1577. [PubMed: 17322066]

Adachi Y, Bradford BU, Gao W, Bojes HK, Thurman RG. Inactivation of Kupffer cells prevents early alcohol-induced liver injury. Hepatology. 1994; 20:453-460. [PubMed: 8045507]

Adachi Y, Moore LE, Bradford BU, Gao W, Thurman RG. Antibiotics prevent liver injury in rats following long-term exposure to ethanol. Gastroenterology. 1995; 108:218-224. [PubMed: 7806045]

Affo S, Dominguez M, Lozano JJ, Sancho-Bru P, Rodrigo-Torres D, Morales-Ibanez O, Bataller R. Transcriptome analysis identifies TNF superfamily receptors as potential therapeutic targets in alcoholic hepatitis. Gut. 2013; 62:452-460. [PubMed: 22637703]

Affo S, Morales-Ibanez O, Rodrigo-Torres D, Altamirano J, Blaya D, Dapito DH, Sancho-Bru P. CCL20 mediates lipopolysaccharide induced liver injury and is a potential driver of inflammation and fibrosis in alcoholic hepatitis. Gut. 2014; 63:1782-1792. [PubMed: 24415562]

Afford SC, Fisher NC, Neil DA, Fear J, Brun P, Hubscher SG, Adams DH. Distinct patterns of chemokine expression are associated with leukocyte recruitment in alcoholic hepatitis and alcoholic cirrhosis. The Journal of Pathology. 1998; 186:82-89. [PubMed: 9875144]

Albano E, Vidali M. Immune mechanisms in alcoholic liver disease. Genes \& Nutrition. 2010; 5:141147. [PubMed: 19809845]

Altamirano J, Miquel R, Katoonizadeh A, Abraldes JG, Duarte-Rojo A, Louvet A, Bataller R. A histologic scoring system for prognosis of patients with alcoholic hepatitis. Gastroenterology. 2014; 146(1231-1239):e1231-e1236.

Ambade A, Satishchandran A, Szabo G. Alcoholic hepatitis accelerates early hepatobiliary cancer by increasing stemness and miR-122-mediated HIF-1alpha activation. Scientific Reports. 2016; 6:21340. [PubMed: 26888602] 
Aoki N, Kido M, Iwamoto S, Nishiura H, Maruoka R, Tanaka J, Watanabe N. Dysregulated generation of follicular helper $\mathrm{T}$ cells in the spleen triggers fatal autoimmune hepatitis in mice.

Gastroenterology. 2011; 140(1322-1333):e1321-e1325.

Apte UM, Banerjee A, McRee R, Wellberg E, Ramaiah SK. Role of osteopontin in hepatic neutrophil infiltration during alcoholic steatohepatitis. Toxicology and Applied Pharmacology. 2005; 207:2538. [PubMed: 15885730]

Bala S, Csak T, Saha B, Zatsiorsky J, Kodys K, Catalano D, Szabo G. The proinflammatory effects of miR-155 promote liver fibrosis and alcohol-induced steatohepatitis. Journal of Hepatology. 2016; 64:1378-1387. [PubMed: 26867493]

Bala S, Marcos M, Kodys K, Csak T, Catalano D, Mandrekar P, Szabo G. Upregulation of microRNA-155 in macrophages contributes to increased tumor necrosis factor $\{$ alpha\} (TNF $\{$ alpha $\}$ ) production via increased mRNA half-life in alcoholic liver disease. The Journal of Biological Chemistry. 2011; 286:1436-1444. [PubMed: 21062749]

Bala S, Petrasek J, Mundkur S, Catalano D, Levin I, Ward J, Szabo G. Circulating microRNAs in exosomes indicate hepatocyte injury and inflammation in alcoholic, drug-induced, and inflammatory liver diseases. Hepatology. 2012; 56:1946-1957. [PubMed: 22684891]

Bala S, Szabo G. MicroRNA signature in alcoholic liver disease. International Journal of Hepatology. 2012; 2012:498232. [PubMed: 22518321]

Bandyopadhyay K, Marrero I, Kumar V. NKT cell subsets as key participants in liver physiology and pathology. Cellular \& Molecular Immunology. 2016; 13:337-346. [PubMed: 26972772]

Banerjee A, Apte UM, Smith R, Ramaiah SK. Higher neutrophil infiltration mediated by osteopontin is a likely contributing factor to the increased susceptibility of females to alcoholic liver disease. The Journal of Pathology. 2006; 208:473-485. [PubMed: 16440289]

Bautista AP. Chronic alcohol intoxication induces hepatic injury through enhanced macrophage inflammatory protein-2 production and intercellular adhesion molecule-1 expression in the liver. Hepatology. 1997; 25(2):335-342. [PubMed: 9021944]

Bautista AP. Neutrophilic infiltration in alcoholic hepatitis. Alcohol. 2002; 27:17-21. [PubMed: 12062632]

Ben-Eliyahu S, Page GG, Yirmiya R, Taylor AN. Acute alcohol intoxication suppresses natural killer cell activity and promotes tumor metastasis. Nature Medicine. 1996; 2:457-460.

Bertola A, Park O, Gao B. Chronic plus binge ethanol feeding synergistically induces neutrophil infiltration and liver injury in mice: A critical role for E-selectin. Hepatology. 2013; 58:18141823. [PubMed: 23532958]

Blaya D, Coll M, Rodrigo-Torres D, Vila-Casadesus M, Altamirano J, Llopis M, Sancho-Bru P. Integrative microRNA profiling in alcoholic hepatitis reveals a role for microRNA-182 in liver injury and inflammation. Gut. 2016; 65:1535-1545. [PubMed: 27196584]

Bode JC, Bode C, Heidelbach R, Durr HK, Martini GA. Jejunal microflora in patients with chronic alcohol abuse. Hepato-Gastroenterology. 1984; 31:30-34. [PubMed: 6698486]

Bode C, Kolepke R, Schafer K, Bode JC. Breath hydrogen excretion in patients with alcoholic liver disease-Evidence of small intestinal bacterial overgrowth. Zeitschrift für Gastroenterologie. 1993; 31:3-7. [PubMed: 8447153]

Boetticher NC, Peine CJ, Kwo P, Abrams GA, Patel T, Aqel B, Shah VH. A randomized, doubleblinded, placebo-controlled multicenter trial of etanercept in the treatment of alcoholic hepatitis. Gastroenterology. 2008; 135:1953-1960. [PubMed: 18848937]

Bull-Otterson L, Feng W, Kirpich I, Wang Y, Qin X, Liu Y, Barve S. Metagenomic analyses of alcohol induced pathogenic alterations in the intestinal microbiome and the effect of Lactobacillus rhamnosus GG treatment. PLoS One. 2013; 8:e53028. [PubMed: 23326376]

Buschard K, Hansen AK, Jensen K, Lindenbergh-Kortleve DJ, de Ruiter LF, Krohn TC, Nieuwenhuis EE. Alcohol facilitates CD1d loading, subsequent activation of NKT cells, and reduces the incidence of diabetes in NOD mice. PLoS One. 2011; 6:e17931. [PubMed: 21483778]

Bykov I, Jauhiainen M, Olkkonen VM, Saarikoski ST, Ehnholm C, Junnikkala S, Meri S. Hepatic gene expression and lipid parameters in complement C3(-/-) mice that do not develop ethanol-induced steatosis. Journal of Hepatology. 2007; 46:907-914. [PubMed: 17321001] 
Bykov I, Junnikkala S, Pekna M, Lindros KO, Meri S. Effect of chronic ethanol consumption on the expression of complement components and acute-phase proteins in liver. Clinical Immunology. 2007; 124:213-220. [PubMed: 17586095]

Byun JS, Suh YG, Yi HS, Lee YS, Jeong WI. Activation of toll-like receptor 3 attenuates alcoholic liver injury by stimulating Kupffer cells and stellate cells to produce interleukin-10 in mice. Journal of Hepatology. 2013; 58:342-349. [PubMed: 23023014]

Cai Y, Jogasuria A, Yin H, Xu MJ, Hu X, Wang J, You M. The detrimental role played by Lipocalin-2 in alcoholic fatty liver in mice. The American Journal of Pathology. 2016; 186:2417-2428. [PubMed: 27427417]

Cao Q, Mak KM, Lieber CS. Dilinoleoylphosphatidylcholine decreases LPS-induced TNF-alpha generation in Kupffer cells of ethanol-fed rats: Respective roles of MAPKs and NF-kappaB. Biochemical and Biophysical Research Communications. 2002; 294:849-853. [PubMed: 12061785]

Carthew RW, Sontheimer EJ. Origins and mechanisms of miRNAs and siRNAs. Cell. 2009; 136:642655. [PubMed: 19239886]

Chang B, Sang L, Wang Y, Tong J, Zhang D, Wang B. The protective effect of VSL\#3 on intestinal permeability in a rat model of alcoholic intestinal injury. BMC Gastroenterology. 2013; 13:151. [PubMed: 24138544]

Chang B, Xu MJ, Zhou Z, Cai Y, Li M, Wang W, Gao B. Short- or long-term high-fat diet feeding plus acute ethanol binge synergistically induce acute liver injury in mice: An important role for CXCL1. Hepatology. 2015; 62:1070-1085. [PubMed: 26033752]

Chen J, Bao H, Sawyer S, Kunos G, Gao B. Effects of short and long term ethanol on the activation of signal transducer and activator transcription factor 3 in normal and regenerating liver. Biochemical and Biophysical Research Communications. 1997; 239:666-669. [PubMed: 9367825]

Chen P, Torralba M, Tan J, Embree M, Zengler K, Starkel P, Schnabl B. Supplementation of saturated long-chain fatty acids maintains intestinal eubiosis and reduces ethanol-induced liver injury in mice. Gastroenterology. 2015; 148(203-214):e216.

Chen RC, Xu LM, Du SJ, Huang SS, Wu H, Dong JJ, Chen YP. Lactobacillus rhamnosus GG supernatant promotes intestinal barrier function, balances Treg and TH17 cells and ameliorates hepatic injury in a mouse model of chronicbinge alcohol feeding. Toxicology Letters. 2016; 241:103-110. [PubMed: 26617183]

Colmenero J, Bataller R, Sancho-Bru P, Bellot P, Miquel R, Moreno M, Gines P. Hepatic expression of candidate genes in patients with alcoholic hepatitis: Correlation with disease severity. Gastroenterology. 2007; 132:687-697. [PubMed: 17258719]

Cubero FJ, Nieto N. Arachidonic acid stimulates TNFalpha production in Kupffer cells via a reactive oxygen species-pERK1/2-Egr1-dependent mechanism. American Journal of Physiology Gastrointestinal and Liver Physiology. 2012; 303:G228-G239. [PubMed: 22538404]

Cui K, Yan G, Xu C, Chen Y, Wang J, Zhou R, Tian Z. Invariant NKT cells promote alcohol-induced steatohepatitis through interleukin-1beta in mice. Journal of Hepatology. 2015; 62:1311-1318. [PubMed: 25582105]

Das S, Maras JS, Hussain MS, Sharma S, David P, Sukriti S, Sarin SK. Hyperoxidized albumin modulates neutrophils to induce oxidative stress and inflammation in severe alcoholic hepatitis. Hepatology. 2017; 65:631-646. [PubMed: 27775820]

Devalaraja MN, McClain CJ, Barve S, Vaddi K, Hill DB. Increased monocyte MCP-1 production in acute alcoholic hepatitis. Cytokine. 1999; 11:875-881. [PubMed: 10547276]

Diefenbach A, Colonna M, Koyasu S. Development, differentiation, and diversity of innate lymphoid cells. Immunity. 2014; 41:354-365. [PubMed: 25238093]

Dippold RP, Vadigepalli R, Gonye GE, Patra B, Hoek JB. Chronic ethanol feeding alters miRNA expression dynamics during liver regeneration. Alcoholism, Clinical and Experimental Research. 2013; 37(Suppl 1):E59-E69.

Dominguez M, Miquel R, Colmenero J, Moreno M, Garcia-Pagan JC, Bosch J, Bataller R. Hepatic expression of CXC chemokines predicts portal hypertension and survival in patients with alcoholic hepatitis. Gastroenterology. 2009; 136:1639-1650. [PubMed: 19208360] 
Dong X, Liu H, Chen F, Li D, Zhao Y. MiR-214 promotes the alcohol-induced oxidative stress via down-regulation of glutathione reductase and cytochrome $\mathrm{P} 450$ oxidoreductase in liver cells. Alcoholism, Clinical and Experimental Research. 2014; 38:68-77.

Eberl G, Colonna M, Di Santo JP, McKenzie AN. Innate lymphoid cells. Innate lymphoid cells: A new paradigm in immunology. Science. 2015; 348:aaa6566. [PubMed: 25999512]

Eguchi A, Lazaro RG, Wang J, Kim J, Povero D, Willliams B, Feldstein AE. Extracellular vesicles released by hepatocytes from gastric infusion model of alcoholic liver disease contain a MicroRNA barcode that can be detected in blood. Hepatology. 2017; 65:475-490. [PubMed: 27639178]

El-Assal O, Hong F, Kim WH, Radaeva S, Gao B. IL-6-deficient mice are susceptible to ethanolinduced hepatic steatosis: IL- 6 protects against ethanol-induced oxidative stress and mitochondrial permeability transition in the liver. Cellular \& Molecular Immunology. 2004; 1:205-211. [PubMed: 16219169]

Ferrere G, Wrzosek L, Cailleux F, Turpin W, Puchois V, Spatz M, Cassard AM. Fecal microbiota manipulation prevents dysbiosis and alcohol-induced liver injury in mice. Journal of Hepatology. 2017; 66(4):806-815. http://dx.doi.org/10.1016/j.jhep.2016.11.008. [PubMed: 27890791]

Fisher NC, Neil DA, Williams A, Adams DH. Serum concentrations and peripheral secretion of the beta chemokines monocyte chemoattractant protein 1 and macrophage inflammatory protein 1alpha in alcoholic liver disease. Gut. 1999; 45:416-420. [PubMed: 10446112]

Francis H, McDaniel K, Han Y, Liu X, Kennedy L, Yang F, Meng F. Regulation of the extrinsic apoptotic pathway by microRNA-21 in alcoholic liver injury. The Journal of Biological Chemistry. 2014; 289:27526-27539. [PubMed: 25118289]

Gao B, Radaeva S, Park O. Liver natural killer and natural killer T cells: Immunobiology and emerging roles in liver diseases. Journal of Leukocyte Biology. 2009; 86:513-528. [PubMed: 19542050]

Gao B, Shah VH. Combination therapy: New hope for alcoholic hepatitis? Clinics and Research in Hepatology and Gastroenterology. 2015; 39(Suppl 1):S7-S11. [PubMed: 26193867]

Gao B, Tsukamoto H. Inflammation in alcoholic and nonalcoholic fatty liver disease: Friend or foe? Gastroenterology. 2016; 150:1704-1709. [PubMed: 26826669]

Gao B, Xu M. Chemokines and alcoholic hepatitis: Are chemokines good therapeutic targets? Gut. 2014; 63:1683-1684. [PubMed: 24515805]

Ge X, Leung TM, Arriazu E, Lu Y, Urtasun R, Christensen B, Nieto N. Osteopontin binding to lipopolysaccharide lowers tumor necrosis factor-alpha and prevents early alcohol-induced liver injury in mice. Hepatology. 2014; 59:1600-1616. [PubMed: 24214181]

Gonzalez-Reimers E, Sanchez-Perez MJ, Santolaria-Fernandez F, Abreu-Gonzalez P, De la VegaPrieto MJ, Vina-Rodriguez J, Rodriguez-Gaspar M. Changes in cytokine levels during admission and mortality in acute alcoholic hepatitis. Alcohol. 2012; 46:433-440. [PubMed: 22444955]

Grove J, Daly AK, Bassendine MF, Gilvarry E, Day CP. Interleukin 10 promoter region polymorphisms and susceptibility to advanced alcoholic liver disease. Gut. 2000; 46:540-545. [PubMed: 10716685]

Gustot T, Lemmers A, Moreno C, Nagy N, Quertinmont E, Nicaise C, Le Moine O. Differential liver sensitization to toll-like receptor pathways in mice with alcoholic fatty liver. Hepatology. 2006; 43:989-1000. [PubMed: 16628628]

Hammerich L, Bangen JM, Govaere O, Zimmermann HW, Gassler N, Huss S, Tacke F. Chemokine receptor CCR6-dependent accumulation of gammadelta T cells in injured liver restricts hepatic inflammation and fibrosis. Hepatology. 2014; 59:630-642. [PubMed: 23959575]

Han W, Fu X, Xie J, Meng Z, Gu Y, Wang X, Huang W. MiR-26a enhances autophagy to protect against ethanol-induced acute liver injury. Journal of Molecular Medicine. 2015; 93:1045-1055. [PubMed: 25877859]

Hartmann P, Seebauer CT, Schnabl B. Alcoholic liver disease: The gut microbiome and liver cross talk. Alcoholism, Clinical and Experimental Research. 2015; 39:763-775.

Hauge T, Persson J, Danielsson D. Mucosal bacterial growth in the upper gastrointestinal tract in alcoholics (heavy drinkers). Digestion. 1997; 58:591-595. [PubMed: 9438608] 
He, Y., Feng, D., Li, M., Gao, Y., Ramirez, T., Cao, H., Gao, B. HepaticmtDNA-TLR9-microRNA-223 forms a negative feedback loop to limit neutrophil over-activation and acetaminophen hepatotoxicity. Hepatology. 2017. http://dx.doi.org/10.1002/hep.29153

He, Y., Gao, B. A small specific-sized hyaluronic acid ameliorates alcoholic liver disease (ALD) by targeting a small RNA: New hope for ALD therapy?. Hepatology. 2017. http://dx.doi.org/10.1002/ hep.29227

Hill DB, Marsano L, Cohen D, Allen J, Shedlofsky S, McClain CJ. Increased plasma interleukin-6 concentrations in alcoholic hepatitis. The Journal of Laboratory and Clinical Medicine. 1992; 119:547-552. [PubMed: 1583411]

Hill DB, Marsano LS, McClain CJ. Increased plasma interleukin-8 concentrations in alcoholic hepatitis. Hepatology. 1993; 18:576-580. [PubMed: 8359798]

Homann C, Benfield TL, Graudal NA, Garred P. Neopterin and interleukin-8-Prognosis in alcoholinduced cirrhosis. Liver. 2000; 20:442-449. [PubMed: 11169058]

Hong F, Kim WH, Tian Z, Jaruga B, Ishac E, Shen X, Gao B. Elevated interleukin-6 during ethanol consumption acts as a potential endogenous protective cytokine against ethanol-induced apoptosis in the liver: Involvement of induction of Bcl-2 and Bcl-x(L) proteins. Oncogene. 2002; 21:32-43. [PubMed: 11791174]

Hong F, Radaeva S, Pan HN, Tian Z, Veech R, Gao B. Interleukin 6 alleviates hepatic steatosis and ischemia/reperfusion injury in mice with fatty liver disease. Hepatology. 2004; 40:933-941. [PubMed: 15382116]

Horiguchi N, Wang L, Mukhopadhyay P, Park O, Jeong WI, Lafdil F, Gao B. Cell type-dependent proand anti-inflammatory role of signal transducer and activator of transcription 3 in alcoholic liver injury. Gastroenterology. 2008; 134:1148-1158. [PubMed: 18395093]

Hsu SH, Delgado ER, Otero PA, Teng KY, Kutay H, Meehan KM, Duncan AW. MicroRNA-122 regulates polyploidization in the murine liver. Hepatology. 2016; 64:599-615. [PubMed: 27016325]

Huang YS, Chan CY, Wu JC, Pai CH, Chao Y, Lee SD. Serum levels of interleukin-8 in alcoholic liver disease: Relationship with disease stage, biochemical parameters and survival. Journal of Hepatology. 1996; 24:377-384. [PubMed: 8738722]

Iimuro Y, Gallucci RM, Luster MI, Kono H, Thurman RG. Antibodies to tumor necrosis factor alfa attenuate hepatic necrosis and inflammation caused by chronic exposure to ethanol in the rat. Hepatology. 1997; 26:1530-1537. [PubMed: 9397994]

Jaeschke H. Neutrophil-mediated tissue injury in alcoholic hepatitis. Alcohol. 2002; 27:23-27. [PubMed: 12062633]

Jeong WI, Park O, Gao B. Abrogation of the antifibrotic effects of natural killer cells/interferongamma contributes to alcohol acceleration of liver fibrosis. Gastroenterology. 2008; 134:248-258. [PubMed: 18166357]

Jeong WI, Park O, Suh YG, Byun JS, Park SY, Choi E, Gao B. Suppression of innate immunity (natural killer cell/interferon-gamma) in the advanced stages of liver fibrosis in mice. Hepatology. 2011; 53:1342-1351. [PubMed: 21480338]

$\mathrm{Ju}$ C, Tacke F. Hepatic macrophages in homeostasis and liver diseases: From pathogenesis to novel therapeutic strategies. Cellular \& Molecular Immunology. 2016; 13:316-327. [PubMed: 26908374]

Ki SH, Park O, Zheng M, Morales-Ibanez O, Kolls JK, Bataller R, Gao B. Interleukin-22 treatment ameliorates alcoholic liver injury in a murine model of chronic-binge ethanol feeding: Role of signal transducer and activator of transcription 3. Hepatology. 2010; 52:1291-1300. [PubMed: 20842630]

Kishore R, Hill JR, McMullen MR, Frenkel J, Nagy LE. ERK1/2 and Egr-1 contribute to increased TNF-alpha production in rat Kupffer cells after chronic ethanol feeding. American Journal of Physiology Gastrointestinal and Liver Physiology. 2002; 282:G6-15. [PubMed: 11751152]

Kishore R, McMullen MR, Nagy LE. Stabilization of tumor necrosis factor alpha mRNA by chronic ethanol: Role of A + U-rich elements and p38 mitogen-activated protein kinase signaling pathway. The Journal of Biological Chemistry. 2001; 276:41930-41937. [PubMed: 11551956] 
Kong X, Feng D, Mathews S, Gao B. Hepatoprotective and anti-fibrotic functions of interleukin-22: Therapeutic potential for the treatment of alcoholic liver disease. Journal of Gastroenterology and Hepatology. 2013; 28(Suppl 1):56-60. [PubMed: 23855297]

Kono H, Rusyn I, Yin M, Gabele E, Yamashina S, Dikalova A, Thurman RG. NADPH oxidase-derived free radicals are key oxidants in alcohol-induced liver disease. The Journal of Clinical Investigation. 2000; 106:867-872. [PubMed: 11018074]

Kono H, Uesugi T, Froh M, Rusyn I, Bradford BU, Thurman RG. ICAM-1 is involved in the mechanism of alcohol-induced liver injury: Studies with knockout mice. American Journal of Physiology Gastrointestinal and Liver Physiology. 2001; 280:G1289-G1295. [PubMed: 11352823]

Krizhanovsky V, Yon M, Dickins RA, Hearn S, Simon J, Miething C, Lowe SW. Senescence of activated stellate cells limits liver fibrosis. Cell. 2008; 134:657-667. [PubMed: 18724938]

Kwon HJ, Won YS, Park O, Feng D, Gao B. Opposing effects of prednisolone treatment on T/NKT cell- and hepatotoxin-mediated hepatitis in mice. Hepatology. 2014; 59:1094-1106. [PubMed: 24115096]

Laso FJ, Madruga JI, Giron JA, Lopez A, Ciudad J, SanMiguel JF, Orfao A. Decreased natural killer cytotoxic activity in chronic alcoholism is associated with alcohol liver disease but not active ethanol consumption. Hepatology. 1997; 25:1096-1100. [PubMed: 9141423]

Lazaro R, Wu R, Lee S, Zhu NL, Chen CL, French SW, Tsukamoto H. Osteopontin deficiency does not prevent but promotes alcoholic neutrophilic hepatitis in mice. Hepatology. 2015; 61:129-140. [PubMed: 25132354]

Lemmers A, Moreno C, Gustot T, Marechal R, Degre D, Demetter P, Deviere J. The interleukin-17 pathway is involved in human alcoholic liver disease. Hepatology. 2009; 49:646-657. [PubMed: 19177575]

Li M, He Y, Zhou Z, Ramirez T, Gao Y, Gao Y, Gao B. MicroRNA-223 ameliorates alcoholic liver injury by inhibiting the IL-6-p47phox-oxidative stress pathway in neutrophils. Gut. 2017; 66:705715. [PubMed: 27679493]

Liaskou E, Klemsdal Henriksen EK, Holm K, Kaveh F, Hamm D, Fear J, Hirschfield GM. Highthroughput T-cell receptor sequencing across chronic liver diseases reveals distinct diseaseassociated repertoires. Hepatology. 2016; 63:1608-1619. [PubMed: 26257205]

Lippai D, Bala S, Catalano D, Kodys K, Szabo G. Micro-RNA-155 deficiency prevents alcoholinduced serum endotoxin increase and small bowel inflammation in mice. Alcoholism, Clinical and Experimental Research. 2014; 38:2217-2224.

Liu Y, Chen SH, Jin X, Li YM. Analysis of differentially expressed genes and microRNAs in alcoholic liver disease. International Journal of Molecular Medicine. 2013; 31:547-554. [PubMed: 23337955]

Liu H, French BA, Li J, Tillman B, French SW. Altered regulation of miR-34a and miR-483-3p in alcoholic hepatitis and DDC fed mice. Experimental and Molecular Pathology. 2015; 99:552-557. [PubMed: 26403328]

Llopis M, Cassard AM, Wrzosek L, Boschat L, Bruneau A, Ferrere G, Perlemuter G. Intestinal microbiota contributes to individual susceptibility to alcoholic liver disease. Gut. 2016; 65:830839. [PubMed: 26642859]

Luo HY, Ma SF, Qu JF, Tian DH. Effects of Kupffer cell inactivation on graft survival and liver regeneration after partial liver transplantation in rats. Hepatobiliary \& Pancreatic Diseases International. 2015; 14:56-62. [PubMed: 25655291]

Maltby J, Wright S, Bird G, Sheron N. Chemokine levels in human liver homogenates: Associations between GRO alpha and histopathological evidence of alcoholic hepatitis. Hepatology. 1996; 24:1156-1160. [PubMed: 8903391]

Mandrekar P, Ambade A, Lim A, Szabo G, Catalano D. An essential role for monocyte chemoattractant protein-1 in alcoholic liver injury: Regulation of proinflammatory cytokines and hepatic steatosis in mice. Hepatology. 2011; 54:2185-2197. [PubMed: 21826694]

Maricic I, Sheng H, Marrero I, Seki E, Kisseleva T, Chaturvedi S, Kumar V. Inhibition of type I natural killer T cells by retinoids or following sulfatide-mediated activation of type II natural killer T cells attenuates alcoholic liver disease in mice. Hepatology. 2015; 61:1357-1369. [PubMed: 25477000] 
Mathews S, Feng D, Maricic I, Ju C, Kumar V, Gao B. Invariant natural killer T cells contribute to chronic-plus-binge ethanol-mediated liver injury by promoting hepatic neutrophil infiltration. Cellular \& Molecular Immunology. 2016; 13:206-216. [PubMed: 25661730]

Mathews S, Gao B. Therapeutic potential of interleukin 1 inhibitors in the treatment of alcoholic liver disease. Hepatology. 2013; 57:2078-2080. [PubMed: 23609413]

McClain CJ, Barve S, Deaciuc I, Kugelmas M, Hill D. Cytokines in alcoholic liver disease. Seminars in Liver Disease. 1999; 19:205-219. [PubMed: 10422201]

McClain CJ, Cohen DA, Dinarello CA, Cannon JG, Shedlofsky SI, Kaplan AM. Serum interleukin-1 (IL-1) activity in alcoholic hepatitis. Life Sciences. 1986; 39:1479-1485. [PubMed: 3490610]

McMullen MR, Pritchard MT, Wang Q, Millward CA, Croniger CM, Nagy LE. Early growth response-1 transcription factor is essential for ethanol-induced fatty liver injury in mice. Gastroenterology. 2005; 128:2066-2076. [PubMed: 15940638]

Meadows GG, Blank SE, Duncan DD. Influence of ethanol consumption on natural killer cell activity in mice. Alcoholism, Clinical and Experimental Research. 1989; 13:476-479.

Medzhitov R. Origin and physiological roles of inflammation. Nature. 2008; 454:428-435. [PubMed: 18650913]

Meijer C, Wiezer MJ, Diehl AM, Schouten HJ, Schouten HJ, Meijer S, van Leeuwen PA. Kupffer cell depletion by CI2MDP-liposomes alters hepatic cytokine expression and delays liver regeneration after partial hepatectomy. Liver. 2000; 20:66-77. [PubMed: 10726963]

Meng F, Glaser SS, Francis H, Yang F, Han Y, Stokes A, Alpini G. Epigenetic regulation of miR-34a expression in alcoholic liver injury. The American Journal of Pathology. 2012; 181:804-817. [PubMed: 22841474]

Miller AM, Wang H, Bertola A, Park O, Horiguchi N, Ki SH, Gao B. Inflammation-associated interleukin-6/signal transducer and activator of transcription 3 activation ameliorates alcoholic and nonalcoholic fatty liver diseases in interleukin-10-deficient mice. Hepatology. 2011; 54:846856. [PubMed: 21725996]

Mitchell PS, Parkin RK, Kroh EM, Fritz BR, Wyman SK, Pogosova-Agadjanyan EL, Tewari M. Circulating microRNAs as stable blood-based markers for cancer detection. Proceedings of the National Academy of Sciences of the United States of America. 2008; 105:10513-10518. [PubMed: 18663219]

Momen-Heravi F, Bala S, Kodys K, Szabo G. Exosomes derived from alcohol-treated hepatocytes horizontally transfer liver specific miRNA-122 and sensitize monocytes to LPS. Scientific Reports. 2015; 5:9991. [PubMed: 25973575]

Momen-Heravi F, Saha B, Kodys K, Catalano D, Satishchandran A, Szabo G. Increased number of circulating exosomes and their microRNA cargos are potential novel biomarkers in alcoholic hepatitis. Journal of Translational Medicine. 2015; 13:261. [PubMed: 26264599]

Morales-Ibanez O, Dominguez M, Ki SH, Marcos M, Chaves JF, Nguyen-Khac E, Bataller R. Human and experimental evidence supporting a role for osteopontin in alcoholic hepatitis. Hepatology. 2013; 58:1742-1756. [PubMed: 23729174]

Na TY, Han YH, Ka NL, Park HS, Kang YP, Kwon SW, Lee MO. 22-S-hydroxycholesterol protects against ethanol-induced liver injury by blocking the auto/paracrine activation of MCP-1 mediated by LXRalpha. The Journal of Pathology. 2015; 235:710-720. [PubMed: 25557254]

Naveau S, Chollet-Martin S, Dharancy S, Mathurin P, Jouet P, Piquet MA. Foie-Alcool group of the Association Francaise pour l'Etude du F. A double-blind randomized controlled trial of infliximab associated with prednisolone in acute alcoholic hepatitis. Hepatology. 2004; 39:1390 1397. [PubMed: 15122768]

Nguyen-Khac E, Thevenot T, Piquet MA, Benferhat S, Goria O, Chatelain D, Group A-NS. Glucocorticoids plus $\mathrm{N}$-acetylcysteine in severe alcoholic hepatitis. The New England Journal of Medicine. 2011; 365:1781-1789. [PubMed: 22070475]

Nischalke HD, Berger C, Lutz P, Langhans B, Wolter F, Eisenhardt M, Spengler U. Influence of the CXCL1 rs4074 A allele on alcohol induced cirrhosis and HCC in patients of European descent. PLoS One. 2013; 8:e80848. [PubMed: 24260493]

O’Neill LA, Sheedy FJ, McCoy CE. MicroRNAs: The fine-tuners of toll-like receptor signalling. Nature Reviews Immunology. 2011; 11:163-175. 
Oo YH, Banz V, Kavanagh D, Liaskou E, Withers DR, Humphreys E, Adams DH. CXCR3-dependent recruitment and CCR6-mediated positioning of Th-17 cells in the inflamed liver. Journal of Hepatology. 2012; 57:1044-1051. [PubMed: 22796894]

Pan HN, Sun R, Jaruga B, Hong F, Kim WH, Gao B. Chronic ethanol consumption inhibits hepatic natural killer cell activity and accelerates murine cytomegalovirus-induced hepatitis. Alcoholism, Clinical and Experimental Research. 2006; 30:1615-1623.

Park O, Wang H, Weng H, Feigenbaum L, Li H, Yin S, Gao B. In vivo consequences of liver-specific interleukin-22 expression in mice: Implications for human liver disease progression. Hepatology. 2011; 54:252-261. [PubMed: 21465510]

Patel OP, Noor MT, Kumar R, Thakur BS. Serum interleukin 8 and 12 levels predict severity and mortality in patients with alcoholic hepatitis. Indian Journal of Gastroenterology: Official Journal of the Indian Society of Gastroenterology. 2015; 34:209-215. [PubMed: 26108651]

Patouraux S, Bonnafous S, Voican CS, Anty R, Saint-Paul MC, Rosenthal-Allieri MA, Gual P. The osteopontin level in liver, adipose tissue and serum is correlated with fibrosis in patients with alcoholic liver disease. PLoS One. 2012; 7:e35612. [PubMed: 22530059]

Peng JH, Cui T, Huang F, Chen L, Zhao Y, Xu L, Hu YY. Puerarin ameliorates experimental alcoholic liver injury by inhibition of endotoxin gut leakage, Kupffer cell activation, and endotoxin receptors expression. The Journal of Pharmacology and Experimental Therapeutics. 2013; 344:646-654. [PubMed: 23277536]

Peng H, Jiang X, Chen Y, Sojka DK, Wei H, Gao X, Tian Z. Liver-resident NK cells confer adaptive immunity in skin-contact inflammation. The Journal of Clinical Investigation. 2013; 123:14441456. [PubMed: 23524967]

Perez HD, Roll FJ, Bissell DM, Shak S, Goldstein IM. Production of chemotactic activity for polymorphonuclear leukocytes by cultured rat hepatocytes exposed to ethanol. The Journal of Clinical Investigation. 1984; 74:1350-1357. [PubMed: 6434593]

Petrasek J, Bala S, Csak T, Lippai D, Kodys K, Menashy V, Szabo G. IL-1 receptor antagonist ameliorates inflammasome-dependent alcoholic steatohepatitis in mice. The Journal of Clinical Investigation. 2012; 122:3476-3489. [PubMed: 22945633]

Phillips M, Curtis H, Portmann B, Donaldson N, Bomford A, O'Grady J. Antioxidants versus corticosteroids in the treatment of severe alcoholic hepatitis-A randomised clinical trial. Journal of Hepatology. 2006; 44:784-790. [PubMed: 16469404]

Qin X, Gao B. The complement system in liver diseases. Cellular \& Molecular Immunology. 2006; 3:333-340. [PubMed: 17092430]

Radaeva S, Sun R, Jaruga B, Nguyen VT, Tian Z, Gao B. Natural killer cells ameliorate liver fibrosis by killing activated stellate cells in NKG2D-dependent and tumor necrosis factor-related apoptosis-inducing ligand-dependent manners. Gastroenterology. 2006; 130:435-452. [PubMed: 16472598]

Ren YD, Ye ZS, Yang LZ, Jin LX, Wei WJ, Deng YY, Pan JS. Fecal microbiota transplantation induces $\mathrm{HBeAg}$ clearance in patients with positive $\mathrm{HBeAg}$ after long-term antiviral therapy. Hepatology. 2017; 65(5):1756-1768. http://dx.doi.org/10.1002/hep.29008. [PubMed: 28177536]

Richardet JP, Scherman E, Costa C, Campillo B, Bories PN. Combined polymorphisms of tumour necrosis factor alpha and interleukin-10 genes in patients with alcoholic hepatitis. European Journal of Gastroenterology \& Hepatology. 2006; 18:673-679. [PubMed: 16702858]

Roh YS, Zhang B, Loomba R, Seki E. TLR2 and TLR9 contribute to alcohol-mediated liver injury through induction of CXCL1 and neutrophil infiltration. American Journal of Physiology Gastrointestinal and Liver Physiology. 2015; 309:G30-G41. [PubMed: 25930080]

Roll FJ, Alexander M, Perez HD. Generation of chemotactic activity for neutrophils by liver cells metabolizing ethanol. Free Radical Biology \& Medicine. 1989; 7:549-555. [PubMed: 2693223]

Roll FJ, Bissell DM, Perez HD. Human hepatocytes metabolizing ethanol generate a non-polar chemotactic factor for human neutrophils. Biochemical and Biophysical Research Communications. 1986; 137:688-694. [PubMed: 3524561]

Roy N, Mukhopadhyay I, Das K, Pandit P, Majumder PP, Santra A, Chowdhury A. Genetic variants of TNFalpha, IL10, IL1beta, CTLA4 and TGFbeta1 modulate the indices of alcohol-induced liver injury in East Indian population. Gene. 2012; 509:178-188. [PubMed: 22902304] 
Roychowdhury S, McMullen MR, Pritchard MT, Hise AG, van Rooijen N, Medof ME, Nagy LE. An early complement-dependent and TLR-4-independent phase in the pathogenesis of ethanolinduced liver injury in mice. Hepatology. 2009; 49:1326-1334. [PubMed: 19133650]

Rubino SJ, Geddes K, Girardin SE. Innate IL-17 and IL-22 responses to enteric bacterial pathogens. Trends in Immunology. 2012; 33:112-118. [PubMed: 22342740]

Saha B, Bruneau JC, Kodys K, Szabo G. Alcohol-induced miR-27a regulates differentiation and M2 macrophage polarization of normal human monocytes. Journal of Immunology. 2015; 194:30793087.

Saha B, Momen-Heravi F, Kodys K, Szabo G. MicroRNA cargo of extracellular vesicles from alcoholexposed monocytes signals naive monocytes to differentiate into M2 macrophages. The Journal of Biological Chemistry. 2016; 291:149-159. [PubMed: 26527689]

Saikia, P., Bellos, D., McMullen, MR., Pollard, KA., de la Motte, C., Nagy, LE. miR181b-3p and its target importin alpha5 regulate TLR4 signaling in Kupffer cells and liver injury in mice in response to ethanol. Hepatology. 2017. http://dx.doi.org/10.1002/hep.29144

Sawada N, Murata M, Kikuchi K, Osanai M, Tobioka H, Kojima T, Chiba H. Tight junctions and human diseases. Medical Electron Microscopy: Official Journal of the Clinical Electron Microscopy Society of Japan. 2003; 36:147-156. [PubMed: 14505058]

Seth D, Duly A, Kuo PC, McCaughan GW, Haber PS. Osteopontin is an important mediator of alcoholic liver disease via hepatic stellate cell activation. World Journal of Gastroenterology. 2014; 20:13088-13104. [PubMed: 25278703]

Sheron N, Bird G, Koskinas J, Portmann B, Ceska M, Lindley I, Williams R. Circulating and tissue levels of the neutrophil chemotaxin interleukin-8 are elevated in severe acute alcoholic hepatitis, and tissue levels correlate with neutrophil infiltration. Hepatology. 1993; 18:41-46. [PubMed: 8325620]

Shi W, Zhu Q, Gu J, Liu X, Lu L, Qian X, Li G. Anti-IL-17 antibody improves hepatic steatosis by suppressing interleukin-17-related fatty acid synthesis and metabolism. Clinical \& Developmental Immunology. 2013; 2013:253046. [PubMed: 24396389]

Shigehara K, Yokomuro S, Ishibashi O, Mizuguchi Y, Arima Y, Kawahigashi Y, Uchida E. Real-time PCR-based analysis of the human bile microRNAome identifies miR-9 as a potential diagnostic biomarker for biliary tract cancer. PLoS One. 2011; 6:e23584. [PubMed: 21858175]

Shiratori Y, Hikiba Y, Mawet E, Niwa Y, Matsumura M, Kato N, Shiina S, Tada M, Komatsu Y, Kawabe T, et al. Modulation of KC/gro protein (interleukin- 8 related protein in rodents) release from hepatocytes by biologically active mediators. Biochemical and Biophysical Research Communications. 1994; 203:1398-1403. [PubMed: 7945286]

Simerzin A, Zorde-Khvalevsky E, Rivkin M, Adar R, Zucman-Rossi J, Couchy G, Galun E. The liverspecific microRNA-122*, the complementary strand of microRNA-122, acts as a tumor suppressor by modulating the p53/mouse double minute 2 homolog circuitry. Hepatology. 2016; 64:1623-1636. [PubMed: 27302319]

Singh V, Sharma AK, Narasimhan RL, Bhalla A, Sharma N, Sharma R. Granulocyte colonystimulating factor in severe alcoholic hepatitis: A randomized pilot study. The American Journal of Gastroenterology. 2014; 109:1417-1423. [PubMed: 24935272]

Sonnenberg GF, Artis D. Innate lymphoid cells in the initiation, regulation and resolution of inflammation. Nature Medicine. 2015; 21:698-708.

Stewart S, Prince M, Bassendine M, Hudson M, James O, Jones D, Day CP. A randomized trial of antioxidant therapy alone or with corticosteroids in acute alcoholic hepatitis. Journal of Hepatology. 2007; 47:277-283. [PubMed: 17532088]

Stickel F, Dubuquoy L. MicroRNA in alcoholic hepatitis: Implications for pathophysiology and treatment. Gut. 2016; 65:1400-1401. [PubMed: 27252446]

Stoy S, Sandahl TD, Dige AK, Agnholt J, Rasmussen TK, Gronbaek H, Vilstrup H. Highest frequencies of interleukin-22-producing $\mathrm{T}$ helper cells in alcoholic hepatitis patients with a favourable short-term course. PLoS One. 2013; 8:e55101. [PubMed: 23372820]

Sun Z, Klein AS, Radaeva S, Hong F, El-Assal O, Pan HN, Gao B. In vitro interleukin-6 treatment prevents mortality associated with fatty liver transplants in rats. Gastroenterology. 2003; 125:202-215. [PubMed: 12851884] 
Swiatkowska-Stodulska R, Bakowska A, Drobinska-Jurowiecka A. Interleukin-8 in the blood serum of patients with alcoholic liver disease. Medical Science Monitor: International Medical Journal of Experimental and Clinical Research. 2006; 12:CR215-CR220. [PubMed: 16641879]

Szabo G, Bala S. Alcoholic liver disease and the gut-liver axis. World Journal of Gastroenterology: WJG. 2010; 16:1321-1329. [PubMed: 20238398]

Szabo G, Bala S. MicroRNAs in liver disease. Nature Reviews Gastroenterology \& Hepatology. 2013; 10:542-552. [PubMed: 23689081]

Takamatsu M, Yamauchi M, Maezawa Y, Saito S, Maeyama S, Uchikoshi T. Genetic polymorphisms of interleukin-1beta in association with the development of alcoholic liver disease in Japanese patients. The American Journal of Gastroenterology. 2000; 95:1305-1311. [PubMed: 10811344]

Tang Y, Banan A, Forsyth CB, Fields JZ, Lau CK, Zhang LJ, Keshavarzian A. Effect of alcohol on miR-212 expression in intestinal epithelial cells and its potential role in alcoholic liver disease. Alcoholism, Clinical and Experimental Research. 2008; 32:355-364.

Tang Y, Zhang L, Forsyth CB, Shaikh M, Song S, Keshavarzian A. The role of miR-212 and iNOS in alcohol-induced intestinal barrier dysfunction and steatohepatitis. Alcoholism, Clinical and Experimental Research. 2015; 39:1632-1641.

Thakur V, Pritchard MT, McMullen MR, Wang Q, Nagy LE. Chronic ethanol feeding increases activation of NADPH oxidase by lipopolysaccharide in rat Kupffer cells: Role of increased reactive oxygen in LPS-stimulated ERK1/2 activation and TNF-alpha production. Journal of Leukocyte Biology. 2006; 79:1348-1356. [PubMed: 16554353]

Thiele GM, Duryee MJ, Willis MS, Tuma DJ, Radio SJ, Hunter CD, Klassen LW. Autoimmune hepatitis induced by syngeneic liver cytosolic proteins biotransformed by alcohol metabolites. Alcoholism, Clinical and Experimental Research. 2010; 34:2126-2136.

Thiele GM, Freeman TL, Klassen LW. Immunologic mechanisms of alcoholic liver injury. Seminars in Liver Disease. 2004; 24:273-287. [PubMed: 15349805]

Thursz MR, Richardson P, Allison M, Austin A, Bowers M, Day CP, Trial S. Prednisolone or pentoxifylline for alcoholic hepatitis. The New England Journal of Medicine. 2015; 372:16191628. [PubMed: 25901427]

Tian F, Chi F, Wang G, Liu X, Zhang Q, Chen Y, Chen W. Lactobacillus rhamnosus CCFM1107 treatment ameliorates alcohol-induced liver injury in a mouse model of chronic alcohol feeding. Journal of Microbiology. 2015; 53:856-863.

Tilg H, Moschen AR, Szabo G. Interleukin-1 and inflammasomes in alcoholic liver disease/acute alcoholic hepatitis and nonalcoholic fatty liver disease/nonalcoholic steatohepatitis. Hepatology. 2016; 64:955-965. [PubMed: 26773297]

Uesugi T, Froh M, Arteel GE, Bradford BU, Thurman RG. Toll-like receptor 4 is involved in the mechanism of early alcohol-induced liver injury in mice. Hepatology. 2001; 34:101-108. [PubMed: 11431739]

Wang S, Ding WX. A small RNA in neutrophils protects against acute-onchronic alcoholic liver injury. Gut. 2017; 66:565-566. [PubMed: 27802158]

Wang H, Feng D, Park O, Yin S, Gao B. Invariant NKT cell activation induces neutrophil accumulation and hepatitis: Opposite regulation by IL-4 and IFN-gamma. Hepatology. 2013; 58:1474-1485. [PubMed: 23686838]

Wang HJ, Gao B, Zakhari S, Nagy LE. Inflammation in alcoholic liver disease. Annual Review of Nutrition. 2012; 32:343-368.

Wang XW, Heegaard NH, Orum H. MicroRNAs in liver disease. Gastroenterology. 2012; 142:14311443. [PubMed: 22504185]

Wang H, Lafdil F, Kong X, Gao B. Signal transducer and activator of transcription 3 in liver diseases: A novel therapeutic target. International Journal of Biological Sciences. 2011; 7:536-550. [PubMed: 21552420]

Wang, W., Xu, MJ., Cai, Y., Zhou, Z., Cao, H., Mukhopadhyay, P., Gao, B. Inflammation is independent of steatosis in a murine model of steatohepatitis. Hepatology. 2017. http://dx.doi.org/ 10.1002/hep.29129

Weber JA, Baxter DH, Zhang S, Huang DY, Huang KH, Lee MJ, Wang K. The microRNA spectrum in 12 body fluids. Clinical Chemistry. 2010; 56:1733-1741. [PubMed: 20847327] 
Wieser V, Adolph TE, Enrich B, Kuliopulos A, Kaser A, Tilg H, Kaneider NC. Reversal of murine alcoholic steatohepatitis by pepducin-based functional blockade of interleukin-8 receptors. Gut. 2017; 66(5):930-938. http://dx.doi.org/10.1136/gutjnl-2015-310344. [PubMed: 26858343]

Wieser V, Tymoszuk P, Adolph TE, Grander C, Grabherr F, Enrich B, Tilg H. Lipocalin 2 drives neutrophilic inflammation in alcoholic liver disease. Journal of Hepatology. 2016; 64:872-880. [PubMed: 26682726]

Xing WW, Zou MJ, Liu S, Xu T, Wang JX, Xu DG. Interleukin-22 protects against acute alcoholinduced hepatotoxicity in mice. Bioscience, Biotechnology, and Biochemistry. 2011; 75:12901294.

Xu M, Chang B, Mathews S, Gao B. New drug targets for alcoholic liver disease. Hepatology International. 2014; 8:S475-S480. http://dx.doi.org/10.1007/s12072-014-9516-X.

Xu MJ, Feng D, Wang H, Guan Y, Yan X, Gao B. IL-22 ameliorates renal ischemia-reperfusion injury by targeting proximal tubule epithelium. Journal of the American Society of Nephrology. 2014; 25:967-977. [PubMed: 24459233]

Xu MJ, Feng D, Wu H, Wang H, Chan Y, Kolls J, Gao B. Liver is the major source of elevated serumlipocalin-2 levels after bacterial infection or partial hepatectomy: A critical role for IL-6/ STAT3. Hepatology. 2015; 61:692-702. [PubMed: 25234944]

Yamashina S, Takei Y, Ikejima K, Enomoto N, Kitamura T, Sato N. Ethanol-induced sensitization to endotoxin in Kupffer cells is dependent upon oxidative stress. Alcoholism, Clinical and Experimental Research. 2005; 29:246S-250S.

Yang K, Du C, Cheng Y, Li Y, Gong J, Liu Z. Augmenter of liver regeneration promotes hepatic regeneration depending on the integrity of Kupffer cell in rat small-for-size liver transplantation. The Journal of Surgical Research. 2013; 183:922-928. [PubMed: 23522454]

Yang, AM., Inamine, T., Hochrath, K., Chen, P., Wang, L., Llorente, C., Schnabl, B. Intestinal fungi contribute to development of alcoholic liver disease. The Journal of Clinical Investigation. 2017. http://dx.doi.org/10.1172/JCI90562

Yang S, Tian Z, Wu Y, van Velkinburgh JC, Ni B. Pivotal roles of ILCs in hepatic diseases. International Reviews of Immunology. 2015; 34:509-522. [PubMed: 25730441]

Yang AM, Wen LL, Yang CS, Wang SC, Chen CS, Bair MJ. Interleukin 10 promoter haplotype is associated with alcoholic liver cirrhosis in Taiwanese patients. The Kaohsiung Journal of Medical Sciences. 2014; 30:291-298. [PubMed: 24835349]

Ye D, Yang K, Zang S, Lin Z, Chau HT, Wang Y, Wang Y. Lipocalin-2 mediates non-alcoholic steatohepatitis by promoting neutrophil-macrophage crosstalk via the induction of CXCR2. Journal of Hepatology. 2016; 65:988-997. [PubMed: 27266617]

Yin H, Hu M, Zhang R, Shen Z, Flatow L, You M. MicroRNA-217 promotes ethanol-induced fat accumulation in hepatocytes by down-regulating SIRT1. The Journal of Biological Chemistry. 2012; 287:9817-9826. [PubMed: 22308024]

Yin H, Liang X, Jogasuria A, Davidson NO, You M. miR-217 regulates ethanol-induced hepatic inflammation by disrupting sirtuin 1-lipin-1 signaling. The American Journal of Pathology. 2015; 185:1286-1296. [PubMed: 25797648]

Yin S, Wang H, Bertola A, Feng D, Xu MJ, Wang Y, Gao B. Activation of invariant natural killer T cells impedes liver regeneration by way of both IFN-gamma- and IL-4-dependent mechanisms. Hepatology. 2014; 60:1356-1366. [PubMed: 24623351]

Yoshiya S, Shirabe K, Imai D, Toshima T, Yamashita Y, Ikegami T, Maehara Y. Blockade of the apelinAPJ system promotes mouse liver regeneration by activating Kupffer cells after partial hepatectomy. Journal of Gastroenterology. 2015; 50:573-582. [PubMed: 25148722]

Zhang Y, Jia Y, Zheng R, Guo Y, Wang Y, Guo H, Sun S. Plasma microRNA-122 as a biomarker for viral-, alcohol-, and chemical-related hepatic diseases. Clinical Chemistry. 2010; 56:1830-1838. [PubMed: 20930130]

Zhang F, Little A, Zhang H. Chronic alcohol consumption inhibits peripheral NK cell development and maturation by decreasing the availability of IL-15. Journal of Leukocyte Biology. 2017; 101(4): 1015-1027. http://dx.doi.org/10.1189/jlb.1A0716-298RR. [PubMed: 27837016] 
Zhang X, Tachibana S, Wang H, Hisada M, Williams GM, Gao B, Sun Z. Interleukin-6 is an important mediator for mitochondrial DNA repair after alcoholic liver injury in mice. Hepatology. 2010; 52:2137-2147. [PubMed: 20931558]

Zhao XJ, Dong Q, Bindas J, Piganelli JD, Magill A, Reiser J, Kolls JK. TRIF and IRF-3 binding to the TNF promoter results in macrophage TNF dysregulation and steatosis induced by chronic ethanol. Journal of Immunology. 2008; 181:3049-3056.

Zhao YY, Xiao M, Zhang CL, Xie KQ, Zeng T. Associations between the tumor necrosis factor-alpha gene and interleukin-10 gene polymorphisms and risk of alcoholic liver disease: A meta-analysis. Clinics and Research in Hepatology and Gastroenterology. 2016; 40:428-439. [PubMed: 26656007]

Zhao H, Zhao C, Dong Y, Zhang M, Wang Y, Li F, Feng W. Inhibition of miR122a by Lactobacillus rhamnosus GG culture supernatant increases intestinal occludin expression and protects mice from alcoholic liver disease. Toxicology Letters. 2015; 234:194-200. [PubMed: 25746479]

Zheng M, Horne W, McAleer JP, Pociask D, Eddens T, Good M, Kolls JK. Therapeutic role of interleukin 22 in experimental intra-abdominal Klebsiella pneumoniae infection in mice. Infection and Immunity. 2016; 84:782-789. [PubMed: 26729763] 


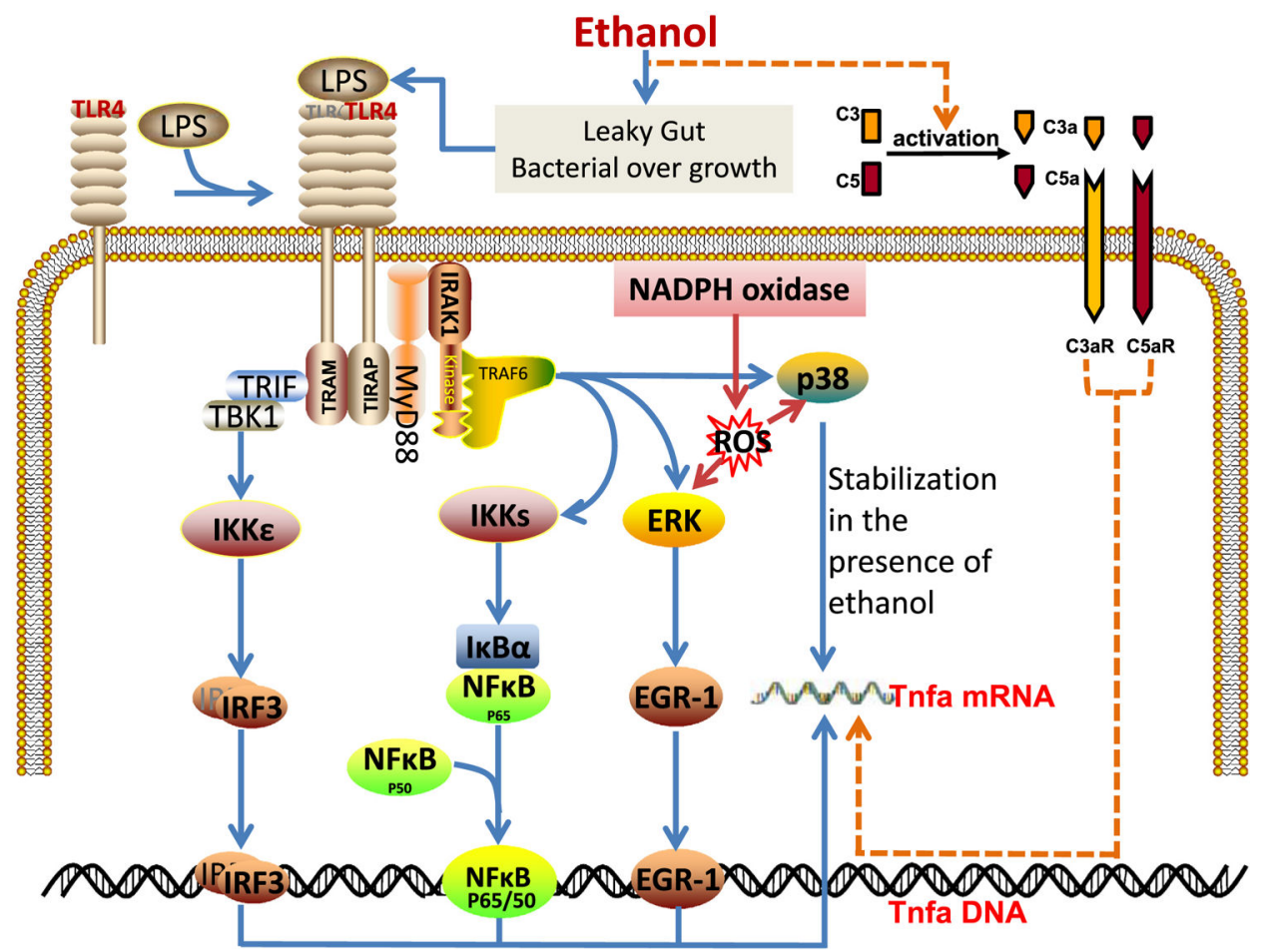

Fig. 1.

Ethanol upregulates TNF-a in Kupffle cells via the activation of multiple pathways Ethanol administration activates the TLR4 pathway, ROS production and complement activation to increase the expression of TNF-a. First, alcohol uptake increases intestine permeability and induces gut bacterial overgrowth. LPS from the intestinal bacteria will translocate into the liver via the portal vein and activates the TLR4 pathway. Upon activation, TLR4 will dimerize and recruit complicated adaptor proteins to initiateMyD88 dependent and independent pathways. A MyD88 dependent pathway mediates the activation of NF- $\kappa \mathrm{B}$, which transactivates the Tnfa gene transcription. A MyD88 independent pathway activates another transcription factor IRF3 to increase the transcription of Tnfa gene transcription. Moreover, the TLR4 signal also activates ERK and p38 MAPK pathways through multiple signal cascades. Activation of ERK increases the activity of EGR-1, an important transcription factor to enhance the expression of Tnfa gene. The p38 signal pathway contributes to the Egr-1 mRNA stabilization in the presence of ethanol, which also increases TNF-a protein production. Second, ethanol treatment increases the ROS production from NADPH oxidase, which may enhance the ERK and p38 pathways. Finally, the C3 and C5 complements are also activated in ethanol-fed mice. The C3aR and C5aR mediated signals increase the Tnfa mRNA through yet unknown mechanisms. 
Table 1

ALD interventions by targeting cytokines

\begin{tabular}{|c|c|c|c|c|}
\hline Targets & Outcome in animal models & References & Outcome in human patients & References \\
\hline \multicolumn{5}{|c|}{ Proinflammatory cytokines } \\
\hline TNF-a & $\begin{array}{l}\text { Anti-TNF-a treatment } \\
\text { reduced hepatic necrosis and } \\
\text { inflammation in rodents. }\end{array}$ & $\begin{array}{l}\text { Iimuro, Gallucci, } \\
\text { Luster, Kono, and } \\
\text { Thurman (1997) }\end{array}$ & $\begin{array}{l}\text { Elevated in circulation and liver } \\
\text { in patients with ALD; TNF- } \\
\text { a-238G > A polymorphism was } \\
\text { associated with ALD risk; } \\
\text { Inhibition of TNF-a increases } \\
\text { bacterial infections in ALD } \\
\text { patients. }\end{array}$ & $\begin{array}{l}\text { McClain, Barve, Deaciuc, } \\
\text { Kugelmas, and Hill (1999) } \\
\text { and references therein, } \\
\text { Zhao, Xiao, Zhang, Xie, } \\
\text { and Zeng (2016), } \\
\text { Boetticher et al. (2008), } \\
\text { Naveau et al. (2004) }\end{array}$ \\
\hline IL-8 & $\begin{array}{l}\text { Blockade of IL- } 8 \text { receptors } \\
\text { (CXCR1/2) reduces liver } \\
\text { injury, inflammation, } \\
\text { steatosis, weight loss and } \\
\text { mortality in mice ALD. }\end{array}$ & $\begin{array}{l}\text { Wieser, Adolph, et al. } \\
\text { (2017) }\end{array}$ & $\begin{array}{l}\text { Elevated in circulation and liver } \\
\text { in AH, correlated with hepatic } \\
\text { neutrophils infiltration, disease } \\
\text { severity and mortality. }\end{array}$ & $\begin{array}{l}\text { Afford et al. (1998), } \\
\text { Dominguez et al. (2009), } \\
\text { Gonzalez-Reimers et al. } \\
\text { (2012), Hill, Marsano, and } \\
\text { McClain (1993), Homann, } \\
\text { Benfield, Graudal, and } \\
\text { Garred (2000), Huang et } \\
\text { al. (1996), Patel, Noor, } \\
\text { Kumar, and Thakur } \\
\text { (2015), Sheron et al. } \\
\text { (1993), Swiatkowska- } \\
\text { Stodulska, Bakowska, and } \\
\text { Drobinska-Jurowiecka } \\
\text { (2006) }\end{array}$ \\
\hline CXCL1 (GRO-a) & $\begin{array}{l}\text { Upregulation of CXCL1 in } \\
\text { the serum and liver in ALD; } \\
\text { Blockage of CXCL1 or its } \\
\text { receptor CXCR } 2 \text { reduces } \\
\text { ALD. }\end{array}$ & $\begin{array}{l}\text { Chang et al. (2015), } \\
\text { Lazaro et al. (2015), } \\
\text { Roh et al. (2015) }\end{array}$ & $\begin{array}{l}\text { CXCL1 rs4074A allele is a } \\
\text { genetic risk factor for alcoholic } \\
\text { cirrhosis; Liver CXCL1 } \\
\text { correlates with hepatic } \\
\text { neutrophils infiltration in } \mathrm{AH} \\
\text { patients. }\end{array}$ & $\begin{array}{l}\text { Nischalke et al. (2013), } \\
\text { Affo et al. (2013), } \\
\text { Dominguez et al. (2009), } \\
\text { Maltby, Wright, Bird, and } \\
\text { Sheron (1996) }\end{array}$ \\
\hline IL-17 & $\begin{array}{l}\text { Serum IL-17 is upregulated } \\
\text { in mice with ALD; Anti- } \\
\text { IL- } 17 \text { ameliorates liver } \\
\text { steatosis. }\end{array}$ & $\begin{array}{l}\text { Chen et al. (2016), Shi } \\
\text { et al. (2013) }\end{array}$ & $\begin{array}{l}\text { Serum IL- } 17 \text { levels and hepatic } \\
\text { IL- } 17^{+} \text {cell infiltration are } \\
\text { elevated in patients with } \mathrm{AH} .\end{array}$ & Stoy et al. (2013) \\
\hline IL-1 & $\begin{array}{l}\text { Serum and hepatic IL-1 } \beta \text { are } \\
\text { elevated in mice with ALD; } \\
\text { IL-1R1 deficiency or IL-1R } \\
\text { antagonist ameliorates } \\
\text { alcohol-induced liver injury }\end{array}$ & Petrasek et al. (2012) & $\begin{array}{l}\text { Serum and hepatic IL-1 levels } \\
\text { correlate with disease severity in } \\
\text { AH patients; IL-1b } 2511 \text {, } \\
2 / 13953 \text { allele } 1 \text { is a risk factor } \\
\text { for alcoholic cirrhosis; IL } 1 \text { b } \\
\text { - } 511 \text { CC genotype affects the } \\
\text { total bilirubin and ALT levels in } \\
\text { alcoholic "Bengalis"; Anakinra, } \\
\text { IL-1R antagonist, and IL-1 } \\
\text { inhibitor, Rilonacept, are being } \\
\text { evaluated in a clinical trial for } \\
\text { severe } 32 \text {; NCT01903798). }\end{array}$ & $\begin{array}{l}\text { McClain et al. (1986), } \\
\text { Takamatsu et al. (2000), } \\
\text { Roy et al. (2012) }\end{array}$ \\
\hline OPN & $\begin{array}{l}\text { Hepatic OPN is elevated in } \\
\text { ethanol-fed rats and mice; } \\
\text { The role of OPN in animal } \\
\text { ALD is still contradictory. }\end{array}$ & $\begin{array}{l}\text { Apte et al. (2005), } \\
\text { Banerjee et al. (2006), } \\
\text { Morales-Ibanez et al. } \\
\text { (2013), Seth, Duly, } \\
\text { Kuo, McCaughan, and } \\
\text { Haber (2014), Ge et } \\
\text { al. (2014), Lazaro et } \\
\text { al. (2015) }\end{array}$ & $\begin{array}{l}\text { Serum and hepatic OPN levels } \\
\text { are elevated in AH patients and } \\
\text { correlate with disease severity } \\
\text { and short-term mortality. }\end{array}$ & $\begin{array}{l}\text { Affo et al. (2013), } \\
\text { Morales-Ibanez et al. } \\
\text { (2013), Patouraux et al. } \\
\text { (2012), Seth et al. (2014) }\end{array}$ \\
\hline CCL20 & $\begin{array}{l}\mathrm{CCl}_{4} \text { plus ethanol or } \mathrm{CCl}_{4} \\
\text { plus LPS induces CCL20 } \\
\text { production in macrophages } \\
\text { and HSCs; silencing CCL20 } \\
\text { ameliorates LPS-induced } \\
\text { liver injury and } \\
\text { inflammation. }\end{array}$ & Affo et al. (2014) & $\begin{array}{l}\text { Serum and hepatic CCL20 levels } \\
\text { are elevated in AH patients and } \\
\text { correlate with disease severity } \\
\text { and short-term mortality. }\end{array}$ & Affo et al. (2014) \\
\hline CCL2/MCP-1 & $\begin{array}{l}\text { Hepatic CCL2 levels are } \\
\text { elevated in ethanol-fed mice. }\end{array}$ & $\begin{array}{l}\text { Mandrekar, Ambade, } \\
\text { Lim, Szabo, and }\end{array}$ & $\begin{array}{l}\text { Serum and hepatic CCL2 levels } \\
\text { are increased in patients with } \\
\text { ALD. }\end{array}$ & $\begin{array}{l}\text { Afford et al. (1998), } \\
\text { Colmenero et al. (2007), } \\
\text { Devalaraja, McClain, }\end{array}$ \\
\hline
\end{tabular}

Pharmacol Ther. Author manuscript; available in PMC 2018 December 01. 


\begin{tabular}{|c|c|c|c|c|}
\hline Targets & Outcome in animal models & References & Outcome in human patients & References \\
\hline & $\begin{array}{l}\text { CCL2 deficiency ameliorates } \\
\text { ALD. }\end{array}$ & $\begin{array}{l}\text { Catalano (2011), Na } \\
\text { et al. (2015) }\end{array}$ & & $\begin{array}{l}\text { Barve, Vaddi, and Hill } \\
\text { (1999), Dominguez et al. } \\
\text { (2009), Fisher, Neil, } \\
\text { Williams, and Adams } \\
\text { (1999) }\end{array}$ \\
\hline LCN2 & $\begin{array}{l}\text { Serum and hepatic LCN2 are } \\
\text { elevated in ethanol-fed mice; } \\
\text { LCN2 deficiency ameliorates } \\
\text { liver steatosis, inflammation } \\
\text { and liver injury after chronic } \\
\text { ethanol feeding. }\end{array}$ & $\begin{array}{l}\text { Bykov, Junnikkala, et } \\
\text { al. (2007), Cai et al. } \\
\text { (2016), Ki et al. } \\
\text { (2010), Wieser, } \\
\text { Tymoszuk, et al. } \\
\text { (2016) }\end{array}$ & $\begin{array}{l}\text { Hepatic LCN2 level are increased } \\
\text { in patients with ALD. }\end{array}$ & $\begin{array}{l}\text { Affo et al. (2013), Wieser, } \\
\text { Tymoszuk, et al. (2016) }\end{array}$ \\
\hline \multicolumn{5}{|c|}{ Anti-inflammatory and hepatoprotective cytokines } \\
\hline IL-6 & $\begin{array}{l}\text { Hepatic IL-6 is upregulated } \\
\text { in ethanol-fed mice; IL-6 KO } \\
\text { exacerbates ALD; IL-6 } \\
\text { treatment ameliorates } \\
\text { ethanol-induced liver injury. }\end{array}$ & $\begin{array}{l}\text { Horiguchi et al. } \\
\text { (2008), El-Assal, } \\
\text { Hong, Kim, Radaeva, } \\
\text { and Gao (2004), Hong } \\
\text { et al. (2002), Zhang, } \\
\text { Tachibana, et al. } \\
\text { (2010), Chen, Bao, } \\
\text { Sawyer, Kunos, and } \\
\text { Gao (1997), Hong et } \\
\text { al. (2004) }\end{array}$ & $\begin{array}{l}\text { Serum IL- } 6 \text { level is elevated in } \\
\text { ALD patients and correlates with } \\
\text { the severity of liver disease. }\end{array}$ & Hill et al. (1992) \\
\hline IL-10 & $\begin{array}{l}\text { IL-10 KO exacerbates liver } \\
\text { inflammation, decreases liver } \\
\text { steatosis and injury in } \\
\text { ethanol-fed mice. }\end{array}$ & Miller et al. (2011) & $\begin{array}{l}\text { The results from clinical studies } \\
\text { on the association of IL-10 } \\
\text { polymorphisms and ASH are } \\
\text { inconsistent. }\end{array}$ & $\begin{array}{l}\text { Grove, Daly, Bassendine, } \\
\text { Gilvarry, and Day (2000), } \\
\text { Richardet, Scherman, } \\
\text { Costa, Campillo, and } \\
\text { Bories (2006), Yang et al. } \\
\text { (2014), Zhao et al. (2016) }\end{array}$ \\
\hline IL-22 & $\begin{array}{l}\text { Administration of IL-22 } \\
\text { reduces acute and chronic } \\
\text { alcohol-fed induced liver } \\
\text { steatosis and injury in mice. }\end{array}$ & $\begin{array}{l}\text { Ki et al. (2010), Xing } \\
\text { et al. (2011) }\end{array}$ & $\begin{array}{l}\text { A phase Ib clinical trial } \\
\text { examining IL-22 treatment in AH } \\
\text { patients is currently ongoing } \\
\text { (NCT01918462). }\end{array}$ & \\
\hline
\end{tabular}


Table 2

The role of miRNAs in ALD

\begin{tabular}{|c|c|c|c|c|}
\hline MicroRNA & Source & Target genes & Outcomes & References \\
\hline $\operatorname{miR}-21$ & Liver & Faslg, Dr5 & $\begin{array}{l}\text { Upregulated in the liver, promote } \\
\text { cell survival, reduce liver injury } \\
\text { and fibrosis }\end{array}$ & Francis et al. (2014) \\
\hline $\operatorname{miR}-26 a$ & Liver & Dusp4, Dusp5 & $\begin{array}{l}\text { Enhances autophagy in liver cells } \\
\text { and ameliorates ethanol-induced } \\
\text { liver injury }\end{array}$ & Han et al. (2015) \\
\hline $\operatorname{miR}-27 \mathrm{a}$ & $\begin{array}{l}\text { Serum EV, monocytes derived } \\
\text { EV, monocytes }\end{array}$ & $S P R Y 2$ & $\begin{array}{l}\text { Elevated in serum EV; Induces M2 } \\
\text { macrophage phenotypes }\end{array}$ & $\begin{array}{l}\text { Saha, Bruneau, Kodys, and } \\
\text { Szabo (2015), Saha, Momen- } \\
\text { Heravi, Kodys, and Szabo } \\
\text { (2016) }\end{array}$ \\
\hline $\operatorname{miR}-34 a$ & Liver, hepatocyte-derived EV & Sirt1, Casp2 & $\begin{array}{l}\text { Increases cell survival and } \\
\text { transformation in vitro }\end{array}$ & $\begin{array}{l}\text { Francis et al. (2014), Liu, } \\
\text { French, Li, Tillman, and French } \\
\text { (2015), Meng et al. (2012) }\end{array}$ \\
\hline $\operatorname{miR}-122$ & Liver, serum/plasma, exosomes & $\begin{array}{l}\text { Hifla, Ccng1 } \\
\text { and Bcl-W}\end{array}$ & $\begin{array}{l}\text { Elevated in plasma/serum and } \\
\text { correlated with liver injury; loss of } \\
\text { miR-122 in the liver increases } \\
\text { stemness, progenitor cell markers } \\
\text { and enhanced EMT }\end{array}$ & $\begin{array}{l}\text { Ambade, Satishchandran, and } \\
\text { Szabo (2016), Bala et al. } \\
\text { (2012), Francis et al. (2014), } \\
\text { Meng et al. (2012), Momen- } \\
\text { Heravi, Bala, Kodys, and Szabo } \\
\text { (2015), Zhang, Jia, et al. (2010) }\end{array}$ \\
\hline $\operatorname{miR}-155$ & $\begin{array}{l}\text { Liver, intestine, macrophages, } \\
\text { serum, exosomes }\end{array}$ & NA & $\begin{array}{l}\text { Upregulated in the liver, } \\
\text { macrophages and serum; promotes } \\
\text { liver steatosis, injury, inflammation } \\
\text { and fibrosis; causes gut leakiness }\end{array}$ & $\begin{array}{l}\text { Bala et al. (2016, 2011, 2012), } \\
\text { Bala and Szabo (2012), Lippai, } \\
\text { Bala, Catalano, Kodys, and } \\
\text { Szabo (2014), Momen-Heravi, } \\
\text { Bala, et al. (2015) }\end{array}$ \\
\hline $\operatorname{miR}-181-3 p$ & $\mathrm{KCs}$ & Kpna1 & $\begin{array}{l}\text { A miR } 181 b-3 p \rightarrow \text { importina } 5 \text { axis } \\
\text { contributes to the ethanol-induced } \\
\text { sensitization of inflammatory } \\
\text { signaling pathways in hepatic } \\
\text { macrophages }\end{array}$ & Saikia et al. (2017) \\
\hline $\operatorname{miR}-182$ & Liver & NA & $\begin{array}{l}\text { Upregulated in liver tissue, } \\
\text { correlates with degree of ductular } \\
\text { reaction, disease severity and short- } \\
\text { term mortality. Blockage of } \\
\text { miR- } 182 \text { reduces liver injury, } \\
\text { inflammation and bile acid } \\
\text { accumulation }\end{array}$ & Blaya et al. (2016) \\
\hline $\operatorname{miR}-212$ & Intestinal Epithelial Cells & $Z o-1$ & $\begin{array}{l}\text { Increased in intestinal epithelial } \\
\text { cells; causes gut leakiness by } \\
\text { down-regulating ZO-1 translation }\end{array}$ & $\begin{array}{l}\text { Tang et al. (2008, 2015), Zhao } \\
\text { et al. (2015) }\end{array}$ \\
\hline $\operatorname{miR}-214$ & Liver & Gsr, Por & $\begin{array}{l}\text { Upregulated in liver; induce } \\
\text { oxidative stress }\end{array}$ & $\begin{array}{l}\text { Dong, Liu, Chen, Li, and Zhao } \\
\text { (2014) }\end{array}$ \\
\hline $\operatorname{miR}-217$ & Liver, macrophage/KCs & Sirt1 & $\begin{array}{l}\text { Upregulated in the liver; promotes } \\
\text { ethanol-induced liver steatosis and } \\
\text { hepatic inflammation }\end{array}$ & $\begin{array}{l}\text { Yin et al. (2012), Yin, Liang, } \\
\text { Jogasuria, Davidson, and You } \\
(2015)\end{array}$ \\
\hline $\operatorname{miR}-223$ & Serum, neutrophils & $I I-6$ & $\begin{array}{l}\text { Increased in serum and neutrophils } \\
\text { leading to hepatic neutrophil } \\
\text { infiltration and liver injury }\end{array}$ & $\begin{array}{l}\text { Li et al. (2017), Wang and Ding } \\
\text { (2017) }\end{array}$ \\
\hline
\end{tabular}

Pharmacol Ther. Author manuscript; available in PMC 2018 December 01. 
Table 3

Ongoing clinical trials for the treatment of AH. Details are taken from clinicaltrials.gov (accessed 8th June 2017) (modified from the reference (Xu, Chang, Mathews, \& Gao, 2014))

\begin{tabular}{|c|c|c|c|c|}
\hline & Experimental treatment & Design & Primary outcome & Title/trial number \\
\hline \multicolumn{5}{|l|}{ Gut microbiota } \\
\hline Probiotics & $\begin{array}{l}\text { Dietary Supplement: } \\
\text { Lactobacillus Rhamnosus } \\
\text { GG }\end{array}$ & Randomised, placebo controlled & $\begin{array}{l}\text { Change in MELD } \\
\text { score after } 30 \\
\text { days }\end{array}$ & $\begin{array}{l}\text { Novel therapies in } \\
\text { moderately severe } \\
\text { acute alcoholic } \\
\text { hepatitis (NTAH- } \\
\text { Moderate) } \\
\text { NCT01922895 }\end{array}$ \\
\hline Antibiotics & $\begin{array}{l}\text { Vancomycin, Gentamycin } \\
\text { and Meropenem }\end{array}$ & $\begin{array}{l}\text { Single group, compared to } \\
\text { historic control group }\end{array}$ & 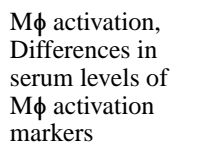 & $\begin{array}{l}\text { The effect of gut } \\
\text { sterilization on } \mathrm{M} \phi \\
\text { activation in } \\
\text { patients with } \mathrm{AH} \\
\text { (NCT03157388) }\end{array}$ \\
\hline $\begin{array}{l}\text { Fecal microbiota } \\
\text { transplantation (FMT) }\end{array}$ & FMT & $\begin{array}{l}\text { Randomised, open label trial } \\
\text { with pentoxifylline as control }\end{array}$ & $\begin{array}{l}\text { Survival at } 3 \\
\text { months }\end{array}$ & $\begin{array}{l}\text { Pentoxyphilline } \\
\text { versus fecal } \\
\text { microbiota therapy } \\
\text { in severe AH } \\
\text { (NCT02458079) }\end{array}$ \\
\hline LPS & $\begin{array}{l}\text { Hyperimmune bovine } \\
\text { colostrum enriched with anti- } \\
\text { LPS antibodies, versus } \\
\text { placebo }\end{array}$ & $\begin{array}{l}\text { Phase 2: randomised, placebo } \\
\text { control }\end{array}$ & $\begin{array}{l}\text { Circulating LPS at } \\
7 \text { months }\end{array}$ & $\begin{array}{l}\text { Safety and efficacy } \\
\text { of IMM 124-E for } \\
\text { patients with severe } \\
\text { AH } \\
\text { (NCT01968382) }\end{array}$ \\
\hline \multicolumn{5}{|l|}{ Immune cell mobilization } \\
\hline G-CSF & G-CSF & $\begin{array}{l}\text { Randomised, placebo controlled } \\
\text { trial }\end{array}$ & $\begin{array}{l}\text { Four and twelve } \\
\text { week survival }\end{array}$ & $\begin{array}{l}\text { Efficacy of G-CSF } \\
\text { in the management } \\
\text { of steroid non- } \\
\text { responsive severe } \\
\text { AH } \\
\text { (NCT01820208) }\end{array}$ \\
\hline $\begin{array}{l}\text { G-CSF and } N \text {-acetylcysteine } \\
\text { (NAC) }\end{array}$ & G-CSF, or G-CSF with NAC & $\begin{array}{l}\text { Phase 4: Randomised, placebo } \\
\text { controlled, open label trial }\end{array}$ & 90-day survival & $\begin{array}{l}\text { G-CSF plus NAC } \\
\text { in severe AH } \\
\text { (NCT02971306) }\end{array}$ \\
\hline LPS & $\begin{array}{l}\text { Hyperimmune bovine } \\
\text { colostrum enriched with anti- } \\
\text { LPS antibodies, versus } \\
\text { placebo }\end{array}$ & $\begin{array}{l}\text { Phase 2: randomised, placebo } \\
\text { controlled double blinded trial }\end{array}$ & $\begin{array}{l}\text { Circulating LPS at } \\
7 \text { months }\end{array}$ & $\begin{array}{l}\text { Safety and efficacy } \\
\text { of IMM 124-E for } \\
\text { patients with severe } \\
\text { AH } \\
\text { (NCT01968382) }\end{array}$ \\
\hline \multicolumn{5}{|l|}{ Cytokine-targeted therapy } \\
\hline IL-1 antagonism & Rilonacept or Mycophenolate & $\begin{array}{l}\text { Phase 2: randomised, open label } \\
\text { trial }\end{array}$ & $\begin{array}{l}\text { Day } 29 \text { survival, } \\
\text { change in } \\
\text { bilirubin }\end{array}$ & $\begin{array}{l}\text { A safety and } \\
\text { efficacy study of } \\
\text { Mycophenolate } \\
\text { Mofetil and } \\
\text { Rilonacept in } \\
\text { patients with AH } \\
\text { (NCT01903798) }\end{array}$ \\
\hline $\begin{array}{l}\text { IL-1 antagonism, TNF } \\
\text { inhibition, gut barrier function }\end{array}$ & $\begin{array}{l}\text { Anakinra, Pentoxifylline, and } \\
\text { Zinc Sulfate versus } \\
\text { methylprednisolone }\end{array}$ & $\begin{array}{l}\text { Phase 2/3: randomised, blinded } \\
\text { trial }\end{array}$ & 6-month survival & $\begin{array}{l}\text { Efficacy study of } \\
\text { Anakinra, } \\
\text { Pentoxifylline, and } \\
\text { Zinc compared to } \\
\text { Methylprednisolone } \\
\text { in severe acute AH } \\
\text { (NCT01809132) }\end{array}$ \\
\hline Recombinant IL-22-Fc protein & IL-22 Fc protein & Phase 1b: & $\begin{array}{l}\text { Safety in AH } \\
\text { patients }\end{array}$ & $\begin{array}{l}\text { Safety and efficacy } \\
\text { of IL-22 protein for } \\
\text { patients with severe } \\
\text { AH } \\
\text { (NCT02655510) }\end{array}$ \\
\hline
\end{tabular}

Pharmacol Ther. Author manuscript; available in PMC 2018 December 01. 


\begin{tabular}{|c|c|c|c|c|}
\hline & Experimental treatment & Design & Primary outcome & Title/trial number \\
\hline \multicolumn{5}{|l|}{ Antibiotics } \\
\hline Rifaximin & $\begin{array}{l}\text { Prednisolone with or without } \\
\text { Rifaximin }\end{array}$ & $\begin{array}{l}\text { Phase 2: single group, open } \\
\text { label }\end{array}$ & $\begin{array}{l}\text { Bacterial } \\
\text { infections at } 90 \\
\text { days }\end{array}$ & $\begin{array}{l}\text { Effects of } \\
\text { Rifaximin in } \\
\text { patients with acute } \\
\text { AH } \\
\text { (NCT02116556) }\end{array}$ \\
\hline Ciprofloxacin & Ciprofloxacin versus placebo & $\begin{array}{l}\text { Phase 1: randomised, open } \\
\text { label, placebo controlled study }\end{array}$ & $\begin{array}{l}\text { 28-day, 3-month } \\
\text { and 6-month } \\
\text { survival }\end{array}$ & NCT02326103 \\
\hline Amoxicillin & Amoxicillin versus placebo & $\begin{array}{l}\text { Phase 3: randomised, double } \\
\text { blinded, placebo controlled trial }\end{array}$ & 2 month survival & $\begin{array}{l}\text { Efficacy of } \\
\text { antibiotic therapy in } \\
\text { severe AH treated } \\
\text { with Prednisolone } \\
\text { (NCT02281929) }\end{array}$ \\
\hline
\end{tabular}

